\title{
IS PRO-LABOR LAW PRO-WOMEN? EVIDENCE FROM INDIA
}

\section{Josef Montag}

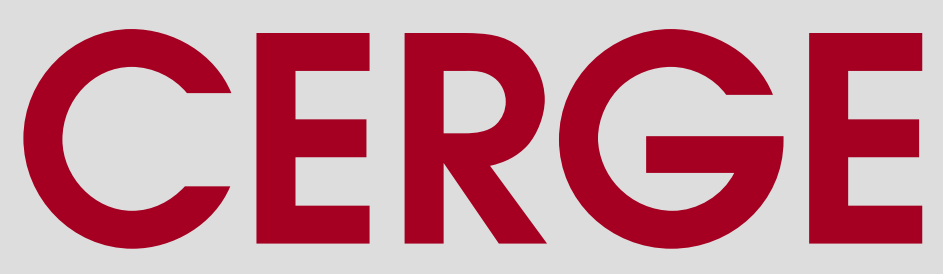




\title{
Working Paper Series 488 (ISSN 1211-3298)
}

\section{Is Pro-Labor Law Pro-Women? Evidence from India}

\author{
Josef Montag
}

CERGE-EI

Prague, August 2013 
ISBN 978-80-7343-292-8 (Univerzita Karlova. Centrum pro ekonomický výzkum a doktorské studium)

ISBN 978-80-7344-284-2 (Národohospodářský ústav AV ČR, v.v.i.) 


\title{
Is Pro-Labor Law Pro-Women? Evidence from India*
}

\author{
Josef Montag ${ }^{\dagger}$ \\ Faculty of Law, Masaryk University and CERGE-EI ${ }^{\ddagger}$
}

August 2013

\begin{abstract}
I study the effects of state-level differences in labor regulation on labor market outcomes of women in India. Using a representative sample of urban households from 2005, I find that labor regulation has a large negative effect on women's economic activity, mainly employment. My estimates suggest that a one standard deviation increase in the labor regulation measure decreases the probability of a woman being economically active by $3 \%$ to $4 \%$ - the implied decrease in female labor force is between $15 \%$ and $18 \%$. The effects on men's participation are around zero. I do not find labor regulation to have a significant effect on male wages or on the gender wage gap. Finally, labor regulation is associated with women having less say at home and a lower sex ratio.
\end{abstract}

\begin{abstract}
Abstrakt
Studie hodnotí efekty rozdílů v mîre regulace pracovně-právních vztahů napříč indickými státy na postavení žen na trhu práce. V reprezentativním vzorku městských domácností z roku 2005 nacházím velké negativní dopady regulace trhů práce na ekonomickou aktivitu žen, zejména na zaměstnanost. Mé odhady naznačují, že zpřísnění regulace trhu práce o jednu standardní odchylku snižuje pravděpodobnost, že žena je ekonomicky aktivní o $3 \%$ až $4 \%$ - to je rovno snížení počtu pracujících žen o $15 \%$ až $18 \%$. Odhady efektů na zaměstnanost mužů se pohybují kolem nuly. Nenacházím ani významné dopady regulace pracovních trhů na mzdy mužů či genderové rozdíly ve mzdách. Regulace trů práce je dále spojena se slabší pozicí žen v domácnostech a nižším podílem žen v populaci.
\end{abstract}

Keywords: gender gap, labor regulation, India.

JEL classification: J16, J21, K31.

${ }^{*}$ For helpful comments I wish to thank Peter Bolcha, Daniele Bondonio, Marian Dobranschi, Libor Dušek, Martin Leroch, Rachna Maheshwari, Alfredo Paloyo, Arkodeb Sinha, participants at the 2013 American Law and Economics Association Annual Meeting, the 2012 Prague Conference on Political Economy, and seminar participants at the University of Economics in Prague. This research was partially funded by dissertation a fellowship at University of Turin, by the Education for Competitiveness Operational Programme project no. CZ.1.07/2.3.00/30.0009, co-financed by the European Social Fund and the state budget of the Czech Republic and by the Czech Science Foundation grant no. P402/12/2172. Parts of this paper were written at Cornell University and Masaryk University. I highly appreciate the support I have received from those institutions as well as from CERGE-EI. Opinions expressed herein are mine and do not represent any of the mentioned institutions. All remaining errors are the responsibility of the author.

${ }^{\dagger}$ Email: josef .montag@cerge-ei.cz.

${ }_{\ddagger}^{\ddagger}$ Center for Economic Research and Graduate Education-Economics Institute, a joint workplace of Charles University in Prague and the Academy of Sciences of the Czech Republic. Address: CERGE-EI, Politických vězňů 7, Prague 1, 111 21, Czech Republic. 


\section{Introduction}

Although women constitute half of the world population, they are a minority in the labor market. They earn lower wages than men and are under-represented in higher levels of the business hierarchy. Yet, what may be a question of well-being or equality in developed societies, can in the developing world be a matter of life and death (Sen 1992).

The position of women in the labor market may be affected by laws and regulations, through their effect on job market opportunities, income inequality, market efficiency, opportunities to discriminate, as well as on decisions regarding the sexual division of labor and investments in human capital. While some laws and policies are specifically aimed at altering labor market outcomes of women, general economic and labor market regulation play an important role because they affect minorities differently from the majority. Labor market regulation may in addition — through its potential effects on women's labor market opportunities - affect the relative importance of men and women in determining family income. This may in turn affect women's position at home as well as influence the emancipation of women in traditional societies.

Do women in India benefit from labor regulation or not? Building on recent research that looks at industry and the macro effects of state-level variation in labor regulation in India, ${ }^{1}$ this study investigates whether and how labor market regulation affects the position of women in labor markets across Indian states. I propose two hypotheses of how these regulations affect women: (i) The equalizing hypothesis, by which I mean the effect of labor market institutions (e.g. collective bargaining, minimum wage laws, and general regulation and policies imposing uniformity) on the wage structure. These policies are aimed at improving the position of workers at the bottom of the income distribution; since women are over-represented at the bottom, labor regulation should disproportionately affect women's remuneration, narrowing the gender gap (Blau and Kahn 2003). (ii) The orthodox view, which is skeptical about such distributional effects, yields the exclusion hypothesis, predicting that the main outcome of regulation will be disemployment. Because

\footnotetext{
${ }^{1}$ See Besley and Burgess (2004); Topalova (2007); Hasan, Mitra, and Ramaswamy (2007); Aghion, Burgess, Redding, and Zilibotti (2008); Ahsan and Pagés (2009).
} 
this will—again disproportionately_affect the marginal workers and women, the result will be greater gender inequality. Note that the inequality in renumeration will in either case decrease; this may, however, be an artifact of disemployment of low wage workers, rather than their experiencing a rise in pay. It follows, that in order to disentangle the two, the effects of labor regulation on employment must be examined first.

The source of variation in labor regulation across Indian states are state-level amendments to the 1947 Industrial Disputes Act (IDA), a central code setting the default rules for employer-worker relations (Malik 2004). For instance, some states have extended the scope of the IDA to smaller firms so that more workers are subject to its protective measures, making a shift in favor of workers. Other amendments have authorised state governments to curb strikes and lock-outs, limiting the powers of labor. Details on the institutional background and related research are provided in Section 2.

The measure of labor regulation developed in this paper is based on Besley and Burgess's (2004) data who code the individual amendments according to their pro-worker or pro-employer content (pro-worker amendments are receive the value of 1, pro-employer amendments get -1). Because Besley and Burgess's labor regulation data end in 1992, I code the amendments that occurred since then and combine the labor regulation measure with the Investment Climate index constructed by Goswami et al. (2002) from a survey of firms in 10 Indian states. Labor market outcomes are obtained from the 2005 India Human Development Survey (IHDS), a nationally representative survey of Indian households. This study focuses on individuals between 18 and 65 years of age living in urban areas of the 16 states for which the labor regulation measure is available. ${ }^{2}$ The focus on urban areas is motivated by the fact that majority of rural population works in agriculture and the IDA does not apply to them. Construction of labor regulation measure and the IHDS data are described in Section 3.

Raw relationships between labor regulation and labor market outcomes of interest are shown in Figure 1. Correlations between labor regulation and economic activity (top row) and between labor regulation and employment (middle row) are negative for both

\footnotetext{
${ }^{2}$ See Table 1 for the list of states. The population of these 16 states constitutes 88 percent of the total population in India.
} 

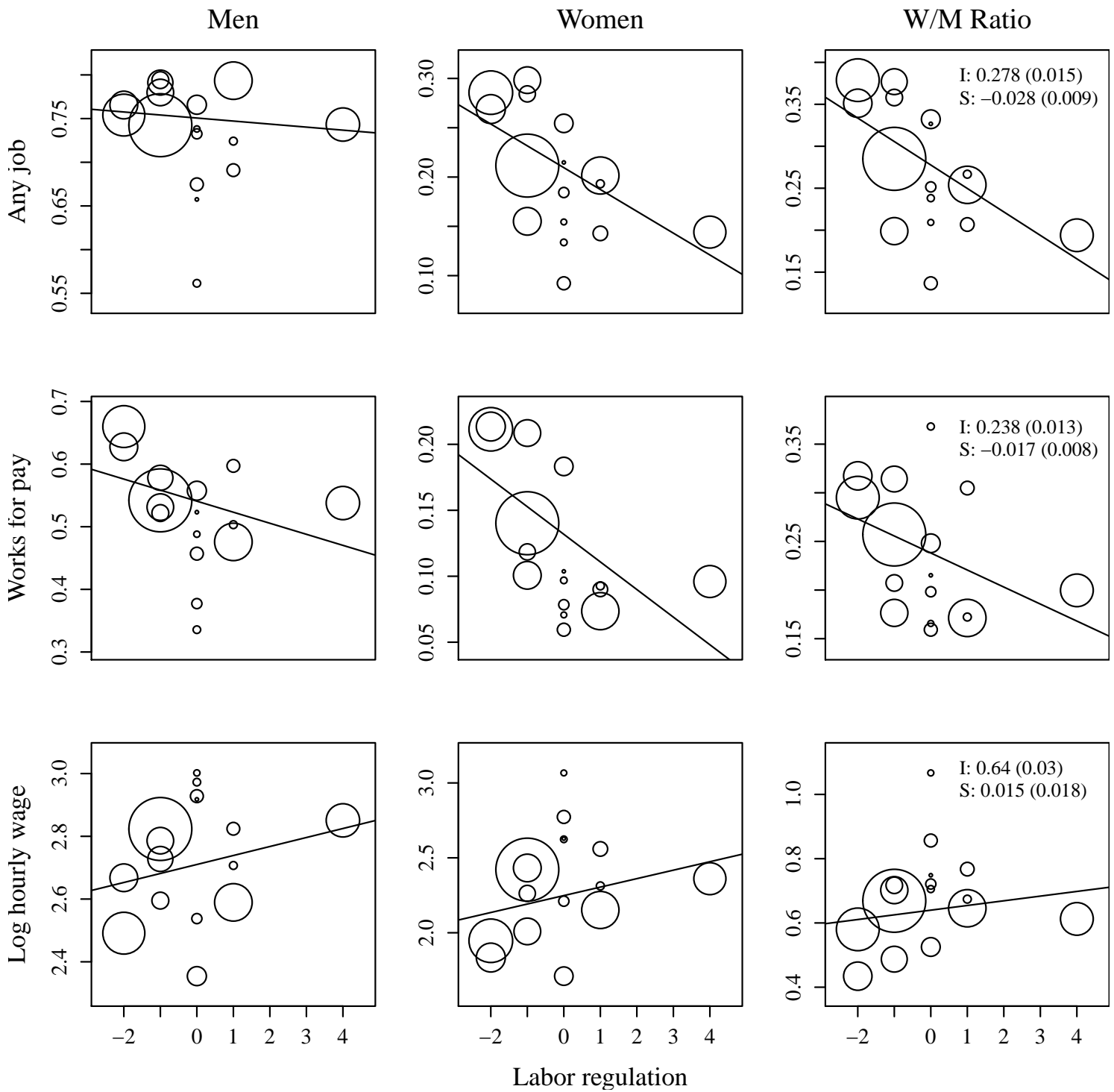

FIG. 1.-Labor regulation (higher numbers signal more pro-worker labor laws) and labor market outcomes across Indian states (urban population between 18 and 65 years of age). Bubbles are proportional to state populations. S: and I: indicate slopes and intercepts from univariate population-weighted regressions of a respective outcome (measured at the state level) on the labor regulation measure; standard errors are in parentheses.

genders. Furthermore, top and middle plots in the far right column indicate that women's relative economic activity and employment (female/male ratio) also decrease within a more rigid regulatory environment, suggesting women are affected more than men; both relationships are substantively as well as statistically significant. Yet, the magnitude of these effects increases dramatically if we take into account the low level of participation of Indian women in the labor force $(21.6 \%)$, making each percentage point a substantively large number. Lastly, a positive relationship between labor regulation and wages as well 
as the gender wage ratio are suggested by the bottom plots; the latter is, however, small and not statistically significant. In probing these relationships econometrically, I find that they hold up to controls for a variety of potentially confounding variables ${ }^{3}$ and extensive specification checks. To address measurement and endogeneity issues, I run IV regressions using historical levels of unionization and patterns of land tenure as instruments for labor regulation. The results are reported and discussed in Sections 4 and 5.

In summary, female participation in the labor force decreases with labor regulation, and I do not find a robust effect of labor regulation on wages or on the gender wage gap. My estimates suggest that a one standard deviation increase in labor regulation measure (1.66) is associated with a $3 \%$ to $4 \%$ decrease in women's economic activity, translating into a $15 \%$ to $18 \%$ decrease in the female labor force. Simultaneously, stricter labor regulation is associated with a higher percentage of women working in agriculture and a lower percentage of women with salaried positions, whereas men in states with more rigid labor laws tend to be self-employed more often. In addition, labor regulation is associated with women having less say within their households and a lower presence of adult women in the population - the latter finding strengthening the results for job market participation and employment. Brief conclusions are offered in Section 6.

This paper delivers three main contributions: First, it contributes to the general literature on institutional determinants of the gender gap (which is discussed in Section 2.1); state-level variability in labor regulation in India represents a rare opportunity to study those determinants while many problems specific to cross-country studies are mitigated. Second, results presented in this study complement the literature analyzing the effects of labor regulation in India (which is discussed in Section 2.2). Third, this study contributes to the scarce literature on the gender gap in developing countries. In fact, no study of gender gap in labor market outcomes in India has, to the best of my knowledge, been published so far.

\footnotetext{
${ }^{3}$ Specifically, I include controls for age, caste and religion membership, poverty status, residence in metropolitan areas, district level unionization, government employment, consumption per capita, share of industries on employment at the state level, as well as the historic characteristics of the Indian states.
} 


\section{Background}

\subsection{Labor Market Institutions and Gender Inequality}

There is a substantial body of literature analyzing international differences in genderrelated labor market outcomes and their relation to general labor market institutions. Blau and Kahn $(2003,1992,1996 b)$ study the effects of wage structure on cross-country differences in gender gap in pay. Because women are over-represented in the lower echelons of the income distribution, countries with less dispersed wages will, ceteris paribus, have smaller wage differences between men and women. The wage structure itself is in turn affected by wage-setting institutions such as collective bargaining, minimum wage arrangements, or comparative worth policies (Blau and Kahn 1996a; DiNardo, Fortin, and Lemieux 1996). ${ }^{4}$

Wage structure effects may however come at a cost—or partially be an artifactof the lower employment of workers at the margin. Differences in male and female unemployment rates in OECD countries were recently analyzed by Azmat, Guell, and Manning (2006). They find high male-female unemployment gaps in Mediterranean countries and small or negative gaps in "Anglo-Saxon" countries. At the same time AngloSaxon countries tend to have more flexible labor laws and weaker labor unions (Botero, Djankov, La Porta, Lopez-de-Silanes, and Shleifer 2004). Cross-country differences in the employment gap between men and women in European Community countries and the United States were studied by Olivetti and Petrongolo (2008). Finding a negative relationship between the gender wage gap and the gender gap in employment, they estimate potential wage offers faced by the unemployed. The estimated median wage gaps are substantially higher for imputed wages compared to the observed wage distribution in countries with high gender-employment gaps (southern EU countries).

Another set of studies looks at how markets and the gender gap interact. Ashenfelter and Hannan (1986) find a negative relationship between market concentration and relative female employment in the banking industry in the U.S. The effects of the U.S. banking

\footnotetext{
${ }^{4}$ However, the relationship may not go in one way only; Fortin and Lemieux (1998) find that the wage distribution itself may be affected by the recent relative wage gains of women.
} 
industry deregulation on the gender gap were then investigated by Black and Strahan (2001). They find that women's relative wages improved and the percentage of women employed in managerial positions rose after deregulation. Zweimüller, Winter-Ebmer, and Weichselbaumer (2008) study the effects of countries' "market orientation" on the residual gender wage gap and find that a free market environment is associated with smaller gaps. Finally, the effects of globalization and international trade were analyzed by Black and Brainerd (2004) and Oostendorp (2009). Both studies find that, despite the negative effects of higher wage inequality, women gain from the increased market competition and trade. These findings are in line with predictions of taste-based models of discrimination (Becker 1957; Alchian and Kessel 1962). Competition and relaxed profit constraints make discrimination costly and therefore less of it is "bought".

\subsection{Labor Regulation in India}

After gaining independence in 1947, India pursued economic policies that relied on highly centralized strategic planning and control. The Industries Act of 1951 implemented an elaborate system of industrial licensing and regulation, whereas all major decisions (e.g. opening up a factory, location change, volume of production, or type of output) were subject to approval by central government officials (Malik 2004). The licensing of industries was dropped in two waves of political reforms in the mid-1980s and early 1990s.

The employment law and the industrial relations law are, on the other hand, a concurrent subject between the central government and individual states. The Industrial Disputes Act (IDA) of 1947 sets the default rules that govern hiring, firing, and relations between employers and labor unions as well as dispute rules. The aim of the IDA is to provide protection for workers against employers. In particular Chapter V-B, introduced in 1976, requires firms to obtain government approval for layoffs, retrenchments and closures. Its scope is, however, limited to permanent employees working in the official-sector firms with more than 100 employees. The law has been frequently amended by states, creating a state-level variation in the extent of regulation of labor markets in India. 
The literature looking at the effects of state-level differences in labor regulation in India was triggered by Besley and Burgess's (2004) paper analyzing the effects of state-level amendments on the manufacturing outcomes in India. They coded individual amendments according to their "pro-worker" or "pro-employer" content and find that more "pro labor" legislation is associated with lower output, employment, investment, and productivity in the formal sector, accompanied by an increase in poverty and output produced in the informal sector.

Ahsan and Pagés (2009) disaggregate state amendments into job security provisions and provisions increasing costs of industrial disputes and find that both types substantially reduce production and employment in the official sector with no improvement in workers' renumeration. The effects of state-level differences in labor regulation on responses to the delicensing of Indian industries were recently analyzed by Aghion et al. (2008). They find that industries located in pro-employer states grew more quickly than those in pro-worker states after delicensing. Topalova $(2007,2010)$ reports that the adverse effects of trade liberalization on poverty across districts were more pronounced in states with inflexible labor laws.

\section{Data and Summary Statistics}

\subsection{Labor Regulation Measure}

The point of departure in developing my measure of labor market regulation is the amendments-based measure constructed by Besley and Burgess (2004). They code state-level amendments to the 1947 Industrial Disputes Act. An amendment receives a value of 1 if it is "pro-worker", -1 if "pro-employer", and 0 if neutral. For instance, West Bengal passed an amendment in 1980, which extends the scope of Chapter V-B (government permission is necessary for layoffs, retrenchment, and closure) to firms with more than 50 employees. This amendment is coded as pro-worker. An amendment enacted in Andhra Pradesh in 1987, which introduced monetary fines and imprisonment for a failure to comply with state government's order constraining industrial dispute activity, is 
an example of a pro-employer change. If more than one amendment was enacted in a given year, the value is still bounded by -1 and 1 and determined by the prevailing tendency. ${ }^{5}$ Adding up amendments across years creates a variation in labor regulation across Indian states.

Because Besley and Burgess's (2004) measure ends in 1992, I reviewed the IDA in a recent edition of Malik (2004) and found nine new state amendments that were enacted after 1992 - they are summarized in Table A1 in the Appendix. With a single exception, all new amendments either repeal or are analogous to earlier amendments. In these cases, I simply follow the precedent coding. The exception is Gujarat's 2004 amendment outlining specific rules for the operation of businesses in special economic zones (SEZ). Units inside a SEZ are normally declared as Public Utility Services under the IDA, which makes their workers exempt from most of its protective provisions. While this amendment introduces some protections for workers in SEZs, the employment rules it creates are less protective in comparison with the level of protection of workers covered by the IDA. I therefore evaluate this amendment as pro-employer. Values of Besley and Burgess's (2004) original labor regulation measure and my updated measure, as of 2004 , for individual states are listed in the first two columns of Table 1. Updating the labor regulation measure with new amendments affects the scores of only two states, Gujarat and Kerala, where both become neutral with a score of zero; the two measures are strongly correlated as reported at the bottom of Table 1 .

However, there has been some criticism of Besley and Burgess's methodology. Bhattacharjea (2006) points to its crudeness and instances of erroneous classification. Yet, as he also notes, if these are random errors resulting from imperfect measurement, the results of Besley and Burgess (2004) are actually strengthened by his critique because their estimates will be biased toward zero. He also notes the fact, that the measure does not take into account other factors that influence the flexibility of labor markets, such as actual enforcement or judicial interpretation. Hasan, Mitra, and Ramaswamy (2007) as well point to the apparent mis-classification in the case of Maharashtra, Gujarat, and

\footnotetext{
${ }^{5}$ Description of individual amendments and their coding by Besley and Burgess (2004) are available at http://econ.lse.ac.uk/staff/rburgess/wp/apptable3.pdf.
} 
Table 1

Labor Regulation Measures

\begin{tabular}{lrccc}
\hline Measure & \multicolumn{2}{c}{ Labor Regulation } & $\begin{array}{c}\text { Investment } \\
\text { Climate }\end{array}$ & $\begin{array}{c}\text { Combined } \\
\text { Index }\end{array}$ \\
Year (Last) & $1992^{1}$ & $2004^{2}$ & $2002^{3}$ & - \\
\hline State: & & & & \\
\cline { 1 - 2 } Pradesh & -2 & -2 & -0.7 & -2 \\
Assam & 0 & 0 & - & 0 \\
Bihar & 0 & 0 & - & 0 \\
Gujarat & 1 & 0 & -2.3 & -1 \\
Haryana & 0 & 0 & - & 0 \\
Jammu \& Kashmir & 0 & 0 & - & 0 \\
Karnataka & -1 & -1 & -0.8 & -1 \\
Kerala & -1 & 0 & 1.6 & 1 \\
Madhya Pradesh & 0 & 0 & - & 0 \\
Maharashtra & 2 & 2 & -3.9 & -1 \\
Orissa & 1 & 1 & - & 1 \\
Punjab & 0 & 0 & 0.1 & 0 \\
Rajasthan & -1 & -1 & - & -1 \\
Tamil Nadu & -2 & -2 & -0.9 & -2 \\
Uttar Pradesh & 0 & 0 & 3.3 & 1 \\
West Bengal & 4 & 4 & 2.2 & 4 \\
\hline Rank correlations & & & &
\end{tabular}

Rank correlations ${ }^{5}$

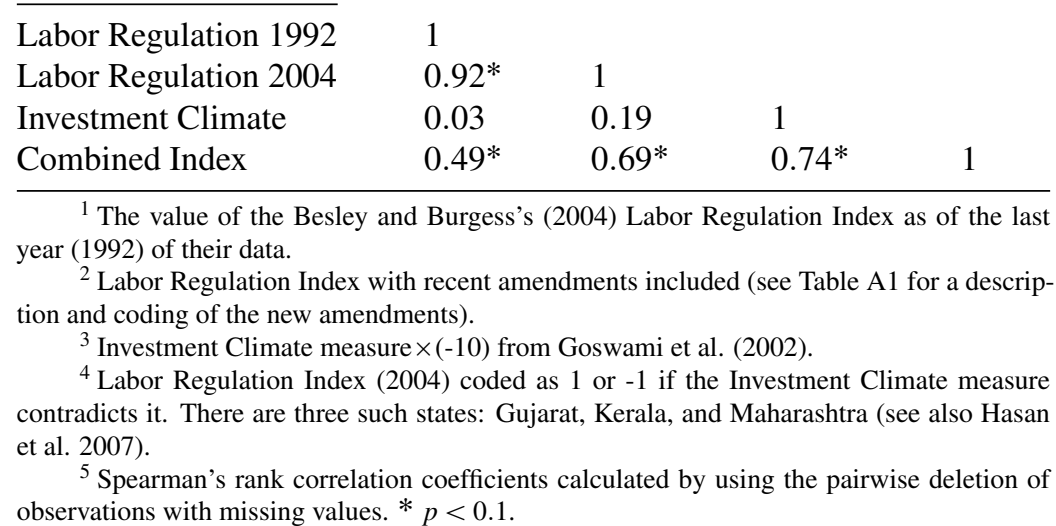

Kerala, based on their industrial records, government politics, and the Investment Climate measure by Goswami et al. (2002).

My preferred measure of labor regulation therefore combines the updated index of Besley and Burgess (2004) and the Investment Climate measure (Goswami et al. 2002), listed in the third column of Table $1 .^{6}$ In particular, where the two indices disagree, I

\footnotetext{
${ }^{6}$ Goswami et al. (2002) survey entrepreneurs and managers in about 1100 manufacturing companies from 10 states operating mostly in four major export industries (textiles, garments, pharmaceuticals, and electronics); 3/4 are small- and medium-sized enterprises (up to 150 workers); the rest are large companies. In particular, they ask the respondent to say which state has the best and which has the worst investment climate. All responses in which the respondent identified his/her own state are dropped and the measure is obtained by netting out the percentage of the sample that considered a specific state to be the worst from the percentage that believed it to be the best. The higher the score, the better the state is perceived.
} 
assign the state a 1 or -1 according to the direction of the Investment Climate measure. This results in changes in 3 states-Maharashtra and Gujarat, which are re-classified from rigid and neutral to flexible, and Kerala, which is re-classified from neutral to rigid. These are the same changes suggested in Hasan, Mitra, and Ramaswamy (2007). ${ }^{7}$ I believe that this measure is better suited to capture the nature of the regulatory frameworks across states in India since formal rules are only one of the many factors affecting an institutional environment. ${ }^{8}$

\subsection{Micro-data}

The individual level data analyzed in this paper come from the 2005 India Human Development Survey (IHDS). ${ }^{9}$ IHDS is a nationally representative, multi-topic survey of 41,554 households in 1,503 villages and 971 urban neighborhoods across India. Two one-hour interviews in each household covered topics concerning health, education, employment, economic status, marriage, fertility, gender relations, and social capital. The reported response rate for the urban sample is 98 percent. Sampling weights are provided and all results or estimates I report use them.

I focus primarily on the urban sample because the majority of workers in rural areas work in agriculture-about 80 percent, of which about half work in family-farm businesses - and the IDA does not apply to them. In addition, law enforcement in general and the reach of government policies may be weaker in rural areas. I nonetheless provide estimates for the rural population as part of the robustness checks.

\footnotetext{
${ }^{7}$ Notice also that the changes in amendment-based measures between 1992 and 2004 are in the same directions in the cases of Gujarat and Kerala.

${ }^{8}$ I check my estimates by replacing the combined labor regulation measure with the index based on Besley and Burgess's (2004) methodology, and the results remain qualitatively similar. This discussion also suggests that it may be imprecise to call these indices labor regulation measures as they are likely to be correlated with additional factors that may not be best described as "pure" labor regulation. One might instead use "business-friendliness" or some similar label as an alternative. On the other hand, labor markets are inseparable from the rest of the economy, so that this problem is rather rhetorical than substantial. To keep continuity with the previous research, I use the term labor regulation throughout this study, but the reader is welcome to interpret the measure as capturing the regulatory environment in a broader sense.

${ }^{9}$ Desai, Vanneman, and the National Council of Applied Economic Research, New Delhi (2010).
} 
Table 2

\section{Individual Characteristics by Gender}

(a) Population

\begin{tabular}{lrrrrr}
\hline & \multicolumn{2}{c}{ Men } & & \multicolumn{2}{c}{ Women } \\
\cline { 2 - 3 } \cline { 6 - 6 } & Mean & S.E. & & Mean & S.E. \\
\hline Labor regulation & -0.23 & $(0.06)$ & & -0.26 & $(0.06)$ \\
\% has any work & 75.29 & $(0.44)$ & & 21.58 & $(0.57)$ \\
\% works for pay & 54.51 & $(0.69)$ & & 13.75 & $(0.47)$ \\
\% works for pay $\geqq 240$ days & 43.85 & $(0.68)$ & & 9.03 & $(0.36)$ \\
\% has a salary job & 33.41 & $(0.74)$ & & 8.14 & $(0.33)$ \\
\% has a non-agricult. wage job & 17.08 & $(0.60)$ & & 3.48 & $(0.27)$ \\
\% works in agriculture & 5.73 & $(0.50)$ & & 6.15 & $(0.42)$ \\
\% works in a family business & 19.07 & $(0.54)$ & & 3.80 & $(0.20)$ \\
Permanent & 17.36 & $(0.59)$ & & 3.19 & $(0.20)$ \\
Log monthly consumption & 6.85 & $(0.02)$ & & 6.83 & $(0.01)$ \\
\% poor & 19.65 & $(0.84)$ & & 20.77 & $(0.87)$ \\
Years of education & 8.74 & $(0.09)$ & 6.74 & $(0.10)$ \\
Age & 36.25 & $(0.11)$ & 35.89 & $(0.10)$ \\
\hline$N$ & 18739 & & 18469 &
\end{tabular}

\section{(b) Wage Labor Force}

\begin{tabular}{|c|c|c|c|c|}
\hline & \multicolumn{2}{|c|}{ Men } & \multicolumn{2}{|c|}{ Women } \\
\hline & Mean & S.E. & Mean & S.E. \\
\hline Labor regulation & -0.30 & $(0.07)$ & -0.66 & $(0.07)$ \\
\hline Log hourly wage & 2.70 & $(0.02)$ & 2.15 & $(0.03)$ \\
\hline$\%$ works for pay & 100.00 & $(0.00)$ & 100.00 & $(0.00)$ \\
\hline$\%$ works for pay $\geqq 240$ days & 80.52 & $(0.84)$ & 65.82 & $(1.69)$ \\
\hline$\%$ has a salary job & 62.00 & $(1.22)$ & 60.01 & $(2.00)$ \\
\hline$\%$ has a non-agricult. wage job & 30.16 & $(1.01)$ & 23.98 & $(1.64)$ \\
\hline$\%$ works in agriculture & 6.79 & $(0.72)$ & 14.88 & $(1.57)$ \\
\hline$\%$ works in a family business & 0.75 & $(0.10)$ & 0.40 & $(0.13)$ \\
\hline Days worked past 24 months & 277.75 & $(1.48)$ & 251.56 & $(3.11)$ \\
\hline Hours worked daily & 8.46 & $(0.03)$ & 7.17 & $(0.06)$ \\
\hline Permanent & 32.71 & $(1.09)$ & 23.89 & $(1.47)$ \\
\hline Log monthly consumption & 6.79 & $(0.02)$ & 6.71 & $(0.02)$ \\
\hline$\%$ poor & 22.50 & $(1.00)$ & 31.05 & $(1.62)$ \\
\hline Years of education & 8.27 & $(0.12)$ & 5.64 & $(0.20)$ \\
\hline Age & 37.19 & $(0.15)$ & 37.26 & $(0.31)$ \\
\hline \multicolumn{5}{|l|}{ Social groups $(\%)$ : } \\
\hline - Brahmin & 7.15 & $(0.46)$ & 4.91 & $(0.54)$ \\
\hline - High caste & 18.61 & $(0.86)$ & 16.13 & $(1.34)$ \\
\hline - Other backward class & 32.23 & $(1.13)$ & 35.22 & $(1.88)$ \\
\hline - Dalit & 19.54 & $(1.08)$ & 24.86 & $(1.84)$ \\
\hline - Adivasi & 2.62 & $(0.38)$ & 3.22 & $(0.69)$ \\
\hline - Muslim & 15.95 & $(1.09)$ & 12.00 & $(1.20)$ \\
\hline - Sikh, Jain & 1.20 & $(0.19)$ & 0.68 & $(0.18)$ \\
\hline - Christian & 2.70 & $(0.45)$ & 2.98 & $(0.64)$ \\
\hline \multicolumn{5}{|l|}{ Industries: } \\
\hline - Agriculture, forestry & 5.82 & $(0.67)$ & 13.94 & $(1.57)$ \\
\hline - Mining & 1.37 & $(0.24)$ & 1.06 & $(0.33)$ \\
\hline - Manufacturing-basic & 10.36 & $(0.62)$ & 17.72 & $(1.74)$ \\
\hline - Manufacturing-complex & 9.09 & $(0.52)$ & 3.73 & $(0.53)$ \\
\hline - Utilities & 3.18 & $(0.26)$ & 0.63 & $(0.18)$ \\
\hline - Construction & 13.03 & $(0.62)$ & 7.47 & $(0.83)$ \\
\hline - Trade, hospitality & 9.62 & $(0.49)$ & 4.64 & $(0.53)$ \\
\hline - Transport, communication & 15.80 & $(0.60)$ & 3.19 & $(0.72)$ \\
\hline - Finance, real estate & 6.18 & $(0.34)$ & 3.84 & $(0.48)$ \\
\hline - Services & 25.56 & $(0.72)$ & 43.78 & $(1.87)$ \\
\hline$N$ & 9527 & & 2324 & \\
\hline
\end{tabular}




\subsubsection{Summary Statistics-Individuals}

Individual-level data, by gender, are summarized in Table 2. Panel (a) describes the entire urban population between 18 and 65 years of age. As we see, women seem to live in states with slightly more flexible labor markets than men although this result is not statistically significant. Women are much less likely to work than men (22\% compared to $75 \%)$ and are relatively more likely to work in agriculture. They are also slightly more likely to be poor and have, on average, two years of education less than men.

Turning the attention to Panel (b), which reports results for an economically active population, we see that working women are more often found in states with weaker labor regulation; this difference is statistically significant. About the same percentage of male and female workers have salaried jobs, while women are about twice as likely to work in agriculture than men. Women work about 25 fewer days per year and one hour less per day than men and are somewhat less likely to work more than 240 days per year or to be permanent workers. Both men and women who work for pay live in households with a smaller consumption per capita than the overall average (compare with Table 3 below). In addition, working women have about an $8 \%$ smaller consumption and are about $9 \%$ more likely to be poor relative to working men. Both men and women who work for pay are less educated than the population mean, but the difference is especially pronounced for women. There are differences in male and female participation across castes and religions, which may reflect differences in attitudes toward male and female work, as well as income differences across these groups. Finally, as suggested above, men and women tend to work in different industries. Women are much more often found in the service sector, but also in basic manufacturing and agriculture. Men work more often in complex manufacturing, construction, trade, transport, and finance.

\subsubsection{Summary Statistics-States}

State-level summary statistics are reported in Table 3. There is a substantial variation in the level of economic well-being across Indian states as suggested by the differences in mean wages, monthly consumption, and poverty rates. Mean consumption per capita in 
the wealthiest states is twice as high as in the poorest ones; more strikingly, the poverty rate varies from 2 to 41 percent. Work activity as well as the proportion of the population that have paid jobs also exhibit a substantial variation across Indian states. Interestingly, the presence of women in the population varies substantially, with a mean of $50 \%$ but with a 7 percentage point spread between the state with the highest and the state with the lowest share of women in the population. Unionization is quite low in India but also varies considerably. There are also statewide differences in women's autonomy within their households, as suggested by the women most-say index.

Shifting attention to the main castes and religions, we see again that their members are not distributed equally across India. For instance, the percentage of the population belonging to High Castes and to Other Backward Classes varies from $4 \%$ to $41 \%$ and $3 \%$ to $60 \%$, respectively. Finally, I use the shares of industries on the labor force to capture the industrial structure of Indian states. We again see considerable variation with the percentage of the urban labor force working in agriculture and forestry ranging from less than $1 \%$ to almost $19 \%$, while those working in basic or complex manufacturing encompass from $2 \%$ to $16 \%$, for instance.

To what extent can these state-wise differences be treated as exogenous-and one should therefore control for them-and to what extent may they be driven by labor regulation or differences in the institutional environment across Indian states? The low mobility of the Indian population (see e.g., Munshi and Rosenzweig 2009; Topalova 2010) suggests it would be appropriate to control for characteristics such as castes, religions, and cohort effects, but labor regulation may well affect the industrial structure in individual states, so controlling for it is controversial. For example, if women are at a disadvantage when applying for jobs in the mining industry but not in services, and if they simultaneously require more contractual flexibility because they are likely to be the secondary earner and carry more household responsibilities, stricter labor regulation may influence the (relative) size of the services industry. Alternatively, agriculture may take a larger share of employment if labor regulations are unlikely to apply there, or if they affect the development of other industries. 
Table 3

Population-weighted State Means

\begin{tabular}{|c|c|c|c|c|c|}
\hline & Mean & Median & S.D. & Min & Max \\
\hline Labor regulation index & -0.24 & -1.00 & 1.66 & -2.00 & 4.00 \\
\hline Log hourly wage & 2.61 & 2.54 & 0.19 & 2.20 & 3.01 \\
\hline Raw log gender-wage gap & -0.47 & -0.44 & 0.18 & -0.83 & 0.06 \\
\hline Log monthly consumption & 6.84 & 6.83 & 0.14 & 6.56 & 7.27 \\
\hline$\%$ poor & 20.41 & 20.82 & 10.06 & 2.23 & 40.86 \\
\hline$\%$ has any work & 48.52 & 48.02 & 4.24 & 36.41 & 54.76 \\
\hline$\%$ works for pay & 34.24 & 34.35 & 5.70 & 22.54 & 43.41 \\
\hline$\%$ works for pay $\geqq 240$ Days & 26.52 & 26.50 & 4.71 & 14.68 & 36.35 \\
\hline$\%$ union members ${ }^{1}$ & 0.08 & 0.07 & 0.08 & 0.00 & 0.45 \\
\hline$\%$ works for government & 0.07 & 0.07 & 0.02 & 0.04 & 0.11 \\
\hline Women most-say index ${ }^{2}$ & 1.34 & 1.36 & 0.26 & 0.95 & 1.93 \\
\hline Age & 36.10 & 35.96 & 0.87 & 34.26 & 37.93 \\
\hline Years of education & 7.75 & 7.90 & 0.73 & 6.64 & 9.05 \\
\hline Share of females in population & 0.50 & 0.49 & 0.01 & 0.46 & 0.53 \\
\hline \multicolumn{6}{|l|}{ Social groups $(\%)$ : } \\
\hline - Brahmin & 7.44 & 6.39 & 4.21 & 0.56 & 17.46 \\
\hline - High caste & 22.28 & 26.13 & 11.37 & 3.68 & 40.90 \\
\hline - Other backward class & 31.38 & 27.50 & 14.12 & 3.12 & 59.34 \\
\hline - Dalit & 16.65 & 16.81 & 4.56 & 7.85 & 27.54 \\
\hline - Adivasi & 2.11 & 1.67 & 2.09 & 0.06 & 6.98 \\
\hline - Muslim & 16.07 & 13.53 & 9.62 & 0.70 & 58.07 \\
\hline - Sikh, Jain & 1.85 & 1.14 & 3.14 & 0.00 & 16.73 \\
\hline - Christian & 2.22 & 1.34 & 2.97 & 0.00 & 14.72 \\
\hline \multicolumn{6}{|c|}{ Industries' share on labor force (\%): } \\
\hline - Agriculture, forestry & 6.96 & 5.51 & 4.71 & 0.45 & 18.75 \\
\hline - Mining & 1.28 & 0.67 & 1.36 & 0.20 & 5.90 \\
\hline - Manufacturing-basic & 11.41 & 11.74 & 3.76 & 1.80 & 15.53 \\
\hline - Manufacturing-complex & 8.05 & 7.05 & 2.80 & 2.04 & 16.01 \\
\hline - Utilities & 2.69 & 2.64 & 1.02 & 0.45 & 6.12 \\
\hline - Construction & 11.86 & 10.51 & 3.95 & 4.91 & 26.30 \\
\hline - Trade, hospitality & 8.59 & 8.71 & 2.20 & 4.70 & 14.58 \\
\hline - Transport, communication & 13.49 & 14.47 & 3.05 & 7.14 & 28.33 \\
\hline - Finance, real estate & 5.80 & 5.28 & 1.61 & 3.13 & 10.02 \\
\hline - Services & 29.87 & 30.50 & 5.05 & 20.80 & 42.41 \\
\hline
\end{tabular}

$N: 16 \quad$ Population estimate: $1.46 \times 10^{8}$

NOTE.-Urban population between 18 and 65 years of age. For variable definitions see Table A6 in the Appendix.

${ }^{1}$ Union membership is only available at the household level. IHDS asks whether "anybody in the household belongs to a trade union, business or professional group".

2 The "women most-say index" counts the number of cases in which the respondent identified herself as the one who has the most say in response to the following 5 questions: What do you cook on a daily basis; whether to buy an expensive item such as a TV or fridge; how many children do you have; what do you do if a child falls sick; and who should your children marry? The respondent is the "eligible woman", i.e. "an ever-married woman between the ages of 15 and 49" in a household.

Similar concerns relate to poverty and consumption levels. Women from poor households may be more likely to work simply because the additional income they provide represents a large marginal value for their families; also women living in districts with a low level of consumption per capita may be more likely to work because they are more likely to be poor themselves, or social pressures against female work may be lower in poor areas. At the same time, the research cited in the previous section shows that inflexible 
labor laws lead to increased poverty. The standard way of addressing such a situation is to present alternative estimates with and without controls in order to gauge these concerns and test the sensitivity of the results.

\section{Methodology and Results}

\subsection{Empirical Model}

To estimate the effects of labor regulation on women's prospects in the labor market, consider a (logit) regression in the form:

$$
y_{i}=\beta_{0}+w_{i}\left(\beta_{w 0}+r_{i} \beta_{w 1}+\mathbf{x}_{\mathbf{i}}^{\prime} \beta_{\mathbf{w} \mathbf{2}}\right)+m_{i}\left(r_{i} \beta_{m 1}+\mathbf{x}_{\mathbf{i}}^{\prime} \beta_{\mathbf{m} \mathbf{2}}\right)+e_{i},
$$

where $y_{i}$ is a dichotomous outcome variable indicating work activity of an individual $i, w_{i}$ and $m_{i}$ indicate whether the respondent $i$ is a woman or a man; $r_{i}$ is the value of the labor regulation measure for a state in which the respondent $i$ lives; $\mathbf{x}_{\mathbf{i}}$ is a vector of control variables the effect of which is allowed to vary for men and women; and $e_{i}$ is the error term. The coefficients of interest are $\beta_{w 1}$ and $\beta_{m 1}$, which estimate the change in log-odds of probability of respondents' being economically active resulting from one unit change in the labor regulation measure, for women and men, respectively.

Causal interpretation of $\beta_{1} \mathrm{~s}$ as the effect of labor regulation requires two assumptions to be satisfied: First, we control for all potentially confounding variables. Second, crossstate differences in labor regulation are not driven by the differences in outcomes. ${ }^{10} \mathrm{I}$ will address these assumptions along with discussing the results.

\footnotetext{
${ }^{10}$ Recall, that the response rate for IHDS is 98 percent, so selection is not an issue when interpreting Regression (1).
} 


\subsection{Participation, Employment, and the Type of Work}

Estimated marginal effects expressed in percents for alternative specifications of Regression (1) are reported in Table 4. ${ }^{11}$ The outcome in the first three columns is defined as taking on a value of 1 if a respondent has had any kind of work during the past 12 months. The estimate on interaction between the women's dummy and the labor regulation measure in column (1), controlling only for castes, religions, and age cohorts, suggest that if the labor regulation measure increases by one unit, the probability a woman has a job decreases by about $2.3 \%$; the effect for men is around zero.

Column (2) reports the results with controls for poverty status, log consumption per capita at a district level, district level of unionization, the government's share on district employment, and with a dummy for residence in large metropolitan areas. The effects of poverty status and district consumption level show the expected signs; the unionization and the government's share on employment are negatively associated with women's employment, which may reflect the disemployment effects of labor unions as well as higher household incomes associated with unionized jobs and government employment. ${ }^{12}$ The estimated effect of labor regulation on women's economic activity, however, does not change and remains highly statistically significant. The third column adds a vector of controls reflecting the industrial structure. ${ }^{13}$ As a result, the estimated effects of labor regulation on women's labor participation slightly decreases but remains statistically and substantively significant.

Note that there is no discernible effect of labor regulation on men's economic activity across the three specifications, as seen in the second part of Table 4. This result makes it unlikely that lower female participation is driven by some variable affecting overall economic activity, such as a business cycle, correlated with our labor regulation measure-

\footnotetext{
${ }^{11}$ Marginal effects are evaluated at the means of explanatory variables separately on men's and women's subsamples.

12 One may also hypothesize, that the higher presence of government or unions may be associated with a greater enforcement of rules and regulations, leading to increased labor costs and lower employment.

13 The shares of the ten one-digit industries on the state's labor force, as reported in Table 3; complex manufacturing is the omitted category.
} 
Table 4

Work, Employment and the Regulation of Labor

\begin{tabular}{|c|c|c|c|c|c|c|c|c|c|}
\hline \multirow[t]{3}{*}{ Outcome: } & \multicolumn{3}{|c|}{ Any Job $(=1)^{1}$} & \multicolumn{6}{|c|}{ Works for Pay $\lesseqgtr 240$ Days (Base Outcome $=0)^{2}$} \\
\hline & \multirow[t]{2}{*}{ (1) } & \multirow[t]{2}{*}{ (2) } & \multirow[t]{2}{*}{ (3) } & \multicolumn{2}{|c|}{ (4) } & \multicolumn{2}{|c|}{ (5) } & \multicolumn{2}{|c|}{ (6) } \\
\hline & & & & $<$ & $\geqq$ & $<$ & $\geqq$ & $<$ & $\geqq$ \\
\hline \multicolumn{10}{|l|}{ Women $\quad(N=18637)$} \\
\hline Labor regulation & $\begin{array}{r}-2.34^{*} \\
(0.41)\end{array}$ & $\begin{array}{r}-2.27^{*} \\
(0.47)\end{array}$ & $\begin{array}{r}-1.96^{*} \\
(0.51)\end{array}$ & $\begin{array}{r}-0.90^{*} \\
(0.17)\end{array}$ & $\begin{array}{c}-1.00^{*} \\
(0.21)\end{array}$ & $\begin{array}{c}-1.00^{*} \\
(0.22)\end{array}$ & $\begin{array}{c}-0.91^{*} \\
(0.21)\end{array}$ & $\begin{array}{r}-0.48^{*} \\
(0.16)\end{array}$ & $\begin{array}{r}-1.01^{*} \\
(0.23)\end{array}$ \\
\hline Poor $(=1)$ & & $\begin{array}{c}9.81^{*} \\
(1.23)\end{array}$ & $\begin{array}{c}9.90^{*} \\
(1.25)\end{array}$ & & & $\begin{array}{c}4.92^{*} \\
(0.75)\end{array}$ & $\begin{array}{c}2.19^{*} \\
(0.57)\end{array}$ & $\begin{array}{c}4.56^{*} \\
(0.72)\end{array}$ & $\begin{array}{c}2.47^{*} \\
(0.58)\end{array}$ \\
\hline Log district consumption p. c. & & $\begin{array}{c}-2.55 \\
(2.58)\end{array}$ & $\begin{array}{c}-3.97 \\
(2.69)\end{array}$ & & & $\begin{array}{c}0.40 \\
(1.04)\end{array}$ & $\begin{array}{c}0.95 \\
(1.00)\end{array}$ & $\begin{array}{c}-0.27 \\
(0.96)\end{array}$ & $\begin{array}{c}0.93 \\
(1.05)\end{array}$ \\
\hline District unionization $\times 10$ & & $\begin{array}{r}-1.52^{*} \\
(0.59)\end{array}$ & $\begin{array}{r}-0.50 \\
(0.77)\end{array}$ & & & $\begin{array}{c}0.28 \\
(0.19)\end{array}$ & $\begin{array}{r}-0.51^{+} \\
(0.25)\end{array}$ & $\begin{array}{c}0.06 \\
(0.30)\end{array}$ & $\begin{array}{c}-0.28 \\
(0.35)\end{array}$ \\
\hline Dist. gov. employment $\times 10$ & & $\begin{array}{r}-4.82^{*} \\
(1.79)\end{array}$ & $\begin{array}{c}-3.19 \\
(2.00)\end{array}$ & & & $\begin{array}{r}-3.95^{*} \\
(0.84)\end{array}$ & $\begin{array}{c}0.23 \\
(0.64)\end{array}$ & $\begin{array}{c}-1.70^{+} \\
(0.73)\end{array}$ & $\begin{array}{c}0.30 \\
(0.77)\end{array}$ \\
\hline 6 metro areas $(=1)$ & & $\begin{array}{r}-3.84^{+} \\
(1.51)\end{array}$ & $\begin{array}{c}-4.87^{*} \\
(1.56)\end{array}$ & & & $\begin{array}{r}-1.39^{*} \\
(0.52)\end{array}$ & $\begin{array}{c}0.96 \\
(0.71)\end{array}$ & $\begin{array}{r}-1.75^{*} \\
(0.43)\end{array}$ & $\begin{array}{c}0.09 \\
(0.68)\end{array}$ \\
\hline \multicolumn{10}{|l|}{ Men $\quad(N=18886)$} \\
\hline Labor regulation & $\begin{array}{c}-0.10 \\
(0.22)\end{array}$ & $\begin{array}{c}0.01 \\
(0.21)\end{array}$ & $\begin{array}{c}0.29 \\
(0.25)\end{array}$ & $\begin{array}{c}0.25 \\
(0.30)\end{array}$ & $\begin{array}{r}-1.68^{*} \\
(0.45)\end{array}$ & $\begin{array}{c}0.22 \\
(0.32)\end{array}$ & $\begin{array}{r}-1.98^{*} \\
(0.43)\end{array}$ & $\begin{array}{c}0.79^{+} \\
(0.31)\end{array}$ & $\begin{array}{r}-2.41^{*} \\
(0.51)\end{array}$ \\
\hline Poor $(=1)$ & & $\begin{array}{c}2.74^{*} \\
(0.78)\end{array}$ & $\begin{array}{c}2.37^{*} \\
(0.77)\end{array}$ & & & $\begin{array}{c}9.72^{*} \\
(1.08)\end{array}$ & $\begin{array}{c}-0.80 \\
(1.45)\end{array}$ & $\begin{array}{c}9.18^{*} \\
(1.05)\end{array}$ & $\begin{array}{c}-0.07 \\
(1.45)\end{array}$ \\
\hline Log district consumption p. c. & & $\begin{array}{c}1.02 \\
(1.38)\end{array}$ & $\begin{array}{c}-0.26 \\
(1.45)\end{array}$ & & & $\begin{array}{c}3.35 \\
(1.72)\end{array}$ & $\begin{array}{c}2.21 \\
(2.65)\end{array}$ & $\begin{array}{c}1.65 \\
(1.83)\end{array}$ & $\begin{array}{c}0.47 \\
(2.83)\end{array}$ \\
\hline District unionization $\times 10$ & & $\begin{array}{r}-1.35^{*} \\
(0.32)\end{array}$ & $\begin{array}{c}-0.69 \\
(0.41)\end{array}$ & & & $\begin{array}{c}2.39^{*} \\
(0.43)\end{array}$ & $\begin{array}{r}-2.97^{*} \\
(0.66)\end{array}$ & $\begin{array}{c}1.96^{*} \\
(0.56)\end{array}$ & $\begin{array}{r}-3.89^{*} \\
(0.87)\end{array}$ \\
\hline Dist. gov. employment $\times 10$ & & $\begin{array}{r}-3.31^{*} \\
(0.82)\end{array}$ & $\begin{array}{c}-3.05^{*} \\
(0.95)\end{array}$ & & & $\begin{array}{r}-9.21^{*} \\
(1.68)\end{array}$ & $\begin{array}{c}4.54^{+} \\
(1.99)\end{array}$ & $\begin{array}{c}-6.06^{*} \\
(1.69)\end{array}$ & $\begin{array}{r}7.10^{*} \\
(2.35)\end{array}$ \\
\hline 6 metro areas $(=1)$ & & $\begin{array}{c}0.66 \\
(0.82)\end{array}$ & $\begin{array}{c}1.38 \\
(0.82)\end{array}$ & & & $\begin{array}{r}-3.82^{*} \\
(1.01)\end{array}$ & $\begin{array}{l}12.32^{*} \\
(1.72)\end{array}$ & $\begin{array}{r}-4.09^{*} \\
(0.94)\end{array}$ & $\begin{array}{c}11.84^{*} \\
(1.89)\end{array}$ \\
\hline $\begin{array}{l}10 \text { industries' shares on } \\
\text { labor-force }\end{array}$ & - & - & Yes & - & - & - & - & Yes & Yes \\
\hline Casts \& religions & Yes & Yes & Yes & Yes & Yes & Yes & Yes & Yes & Yes \\
\hline 5-year cohorts & Yes & Yes & Yes & Yes & Yes & Yes & Yes & Yes & Yes \\
\hline
\end{tabular}

Proportional effects of labor regulation ${ }^{3}$

\begin{tabular}{cccccccccc} 
Women: & -10.84 & -10.53 & -9.08 & -19.21 & -11.10 & -21.32 & -10.10 & -10.22 & -11.17 \\
Men: & $(1.89)$ & $(2.17)$ & $(2.36)$ & $(3.69)$ & $(2.32)$ & $(4.65)$ & $(2.38)$ & $(3.42)$ & $(2.55)$ \\
& $(0.29)$ & $(0.01$ & 0.39 & 2.36 & -3.83 & 2.06 & -4.52 & 7.41 & -5.51 \\
& $(0.33)$ & $(2.82)$ & $(1.03)$ & $(2.99)$ & $(0.98)$ & $(2.91)$ & $(1.16)$ \\
\hline
\end{tabular}

NOTE.-Reported estimates are marginal effects from (multinomial) logit models evaluated at means of explanatory variables, separately for men and women, expressed in percents. Sample: urban population between 18 and 65 years of age. For variable definitions see Table A6 in the Appendix. Standard errors clustered on households are in parentheses: ${ }^{+} p<0.05, * p<0.01$.

${ }^{1}$ The outcome is equal to 1 if a respondent has any job (i.e. works for someone else, in a family business, farm) and has worked more than 240 hours during the last 12 months.

${ }^{2}$ The outcome has 3 possible categories: it is equal to 1 if a respondent works for pay (i.e. works for someone else) and worked less than 240 days (and more than 240 hours) during past 24 months; it is 2 if days worked exceed 240; and it is equal to 0 in other cases (hours worked during a past 12 months are less than 240, or the respondent works in a family business or farm). Coefficients for the 0 category are omitted for brevity; they can be obtained by adding up the coefficients for categories 1 and 2 and multiplying by -1 .

${ }^{3}$ The proportional effects are calculated by dividing absolute value of the respective coefficient by the share of respondents who report a positive outcome on the estimation population. They facilitate an interpretation of the estimated marginal effects from the worker's perspective. 
in which case men's economic activity should be down, too. Rather, this result is consistent with a distinct effect of labor regulation on women's job opportunities. ${ }^{14}$

To better appreciate the magnitude of the estimated effects from an individual's perspective, I compute proportional effects of labor regulation that reflect the share of the labor force being affected rather than the population effect captured by marginal effects. This is done simply by dividing an estimate of the marginal effect by populationshare of those with a positive outcome. Interpretation of these proportional effects is straightforward: They reflect the percentage change in the labor force associated with a one unit change in labor regulation. Estimates of the proportional effects of labor regulation reported at the bottom of Table 4 suggest labor regulation has a substantial impact on the female labor force; with a one unit increase in the labor regulation measure associated with about a $10 \%$ decrease in the female labor force, while the effect on men is around zero. $^{15}$

In order to shed some light on the channels through which labor regulation affects workers, columns (4) through (6) in Table 4 report the results from multinomial logit models, where the outcome is equal to one if a respondent works for pay (i.e. is employed) and worked less than 240 days during the past 24 months; it equals two if days worked exceed 240. It is zero in other cases: self-employed, non-salary workers, and not economically active. This choice is not arbitrary, 240 days worked during the past 12 months is the threshold for temporary workers who are not considered workmen under the IDA and therefore not covered by it; I therefore use this criterion as a crude identificator of workers' status with respect to the IDA. ${ }^{16}$ If labor regulation increases labor costs, standard theory would predict lower employment, particularly in the affected sector. We would also expect a relative increase in self-employment and temporary employment. On the other hand,

\footnotetext{
${ }^{14}$ Because women are marginal workers, it is possible, that their employment is more sensitive to the business cycle than men's employment. However, for the business cycle to drive our results, it would have to be the case that men's economic activity had been completely insensitive to it. I am grateful to Martin Leroch for bringing my attention to this possibility.

15 To look at this concept differently, assume that women and men are viewed equally by the employer, except for the lower share of women who decide to work. If an employer decides to fire some workers because of higher labor costs, each worker should face the same probability of being fired, so the population effects should be smaller for women than men. This is entirely inconsistent with the pattern of our results.

${ }^{16}$ Unfortunately, IHDS data have no information from which one could determine whether the respondent's employer is subject to the IDA.
} 
temporary employment may be opposed by insiders and unions, so that the sign of the effect is to be determined empirically.

Summing up the two coefficients in specification (4) and comparing it to specification (1) reveals that most of the negative effect on women's labor participation works through lower employment; this result holds true in other specifications too. Marginal effects are similar for both categories of workers although the first coefficient in specification (6) loses about half of its size when the industrial structure is controlled for. ${ }^{17}$ Men's employment is also affected by labor regulation: Men are less likely to work more than 240 days, and there is some indication that men are forced into less permanent jobs. If we look at the proportional effects at the bottom of Table 4 we see again that women in the labor force are disproportionately affected, and this effect is especially strong for the probability of working less than 240 days; one unit increase in the labor regulation measure is estimated to decrease the number of women working less than 240 days by $10 \%$ to $21 \%$ and to decrease the number of women working more than 240 days by about $10 \%$, about twice as much as the percentage effect on the men's labor force.

These results appear to support the exclusion hypothesis outlined in the introduction. Women are more likely to be marginal workers and are therefore more likely to disproportionately bear the disemployment costs of regulation. They may also be more likely to leave the market altogether in the absence of suitable opportunities. Disproportionate effects may also be partly driven by a discrimination against women, either by employers or co-workers. Men are more likely to be insiders and to be committed to the labor market if they are the primary breadwinners in their households. This is consistent with an overall smaller effect on men's economic activity as those unable to work for pay may shift to other activities such as self-employment or agricultural labor.

To see how different types of labor market activities are affected by labor regulation, I divide workers into four categories based on their main work activity: agricultural workers, those working in a family business, non-agricultural wage laborers (paid daily), and salaried workers (paid monthly and annually). Table 5 reports the results from multinomial

\footnotetext{
${ }^{17}$ As noted above, the industrial structure itself may be affected by labor regulation; in that case, the coefficient on labor regulation would be biased downwards.
} 


\section{Table 5}

\section{Labor Regulation and the Type of Work}

\begin{tabular}{|c|c|c|c|c|c|c|c|c|c|c|c|c|}
\hline \multirow[b]{2}{*}{ Outcome: Work Type ${ }^{1}$} & \multicolumn{4}{|c|}{ (1) } & \multicolumn{4}{|c|}{ (2) } & \multicolumn{4}{|c|}{ (3) } \\
\hline & Agri. & Busin. & Nonag. & Salary & Agri. & Busin. & Nonag. & Salary & Agri. & Busin. & Nonag. & Salary \\
\hline \multicolumn{13}{|l|}{ Women $\quad(N=3916)$} \\
\hline Labor regulation & $\begin{array}{c}2.84^{+} \\
(1.16)\end{array}$ & $\begin{array}{r}-0.81 \\
(0.43)\end{array}$ & $\begin{array}{c}-1.06 \\
(1.05)\end{array}$ & $\begin{array}{r}-0.98 \\
(0.93)\end{array}$ & $\begin{array}{l}4.15^{*} \\
(1.31)\end{array}$ & $\begin{array}{r}-1.25^{*} \\
(0.48)\end{array}$ & $\begin{array}{c}-0.93 \\
(1.10)\end{array}$ & $\begin{array}{r}-1.97^{+} \\
(0.81)\end{array}$ & $\begin{array}{l}5.11^{*} \\
(1.39)\end{array}$ & $\begin{array}{c}-1.10 \\
(0.58)\end{array}$ & $\begin{array}{r}-1.28 \\
(0.99)\end{array}$ & $\begin{array}{r}-2.73^{*} \\
(0.90)\end{array}$ \\
\hline Poor $(=1)$ & & & & & $\begin{array}{l}8.60^{*} \\
(2.99)\end{array}$ & $\begin{array}{c}-6.27^{*} \\
(1.32)\end{array}$ & $\begin{array}{c}9.56^{*} \\
(2.12)\end{array}$ & $\begin{array}{r}-11.88^{*} \\
(2.26)\end{array}$ & $\begin{array}{c}9.67^{*} \\
(2.92)\end{array}$ & $\begin{array}{c}-7.01^{*} \\
(1.28)\end{array}$ & $\begin{array}{c}9.58 * \\
(2.04)\end{array}$ & $\begin{array}{r}-12.24^{*} \\
(2.15)\end{array}$ \\
\hline Log district consumption p. c. & & & & & $\begin{array}{r}-20.25^{+} \\
(8.38)\end{array}$ & $\begin{array}{r}-0.91 \\
(3.25)\end{array}$ & $\begin{array}{c}10.77^{+} \\
(5.45)\end{array}$ & $\begin{array}{l}10.40^{+} \\
(5.18)\end{array}$ & $\begin{array}{r}-22.75^{*} \\
(8.19)\end{array}$ & $\begin{array}{c}1.22 \\
(3.26)\end{array}$ & $\begin{array}{c}9.46 \\
(5.12)\end{array}$ & $\begin{array}{l}12.07^{+} \\
(5.32)\end{array}$ \\
\hline District unionization $\times 10$ & & & & & $\begin{array}{c}-1.63 \\
(1.76)\end{array}$ & $\begin{array}{c}0.19 \\
(0.81)\end{array}$ & $\begin{array}{c}0.83 \\
(1.13)\end{array}$ & $\begin{array}{c}0.61 \\
(1.28)\end{array}$ & $\begin{array}{l}-2.25 \\
(2.41)\end{array}$ & $\begin{array}{l}1.20 \\
(1.04)\end{array}$ & $\begin{array}{c}0.64 \\
(1.61)\end{array}$ & $\begin{array}{c}0.40 \\
(1.68)\end{array}$ \\
\hline Dist. gov. employment $\times 10$ & & & & & $\begin{array}{c}-8.74 \\
(6.31)\end{array}$ & $\begin{array}{c}3.11 \\
(2.44)\end{array}$ & $\begin{array}{c}-4.99 \\
(3.44)\end{array}$ & $\begin{array}{l}10.63^{*} \\
(3.94)\end{array}$ & $\begin{array}{r}-6.71 \\
(6.56)\end{array}$ & $\begin{array}{c}0.46 \\
(2.72)\end{array}$ & $\begin{array}{r}-3.22 \\
(3.69)\end{array}$ & $\begin{array}{c}9.47^{+} \\
(4.23)\end{array}$ \\
\hline 6 metro areas $(=1)$ & & & & & $\begin{array}{r}-29.45^{*} \\
(4.13)\end{array}$ & $\begin{array}{c}5.18 \\
(2.68)\end{array}$ & $\begin{array}{l}-2.76 \\
(2.83)\end{array}$ & $\begin{array}{l}27.02^{*} \\
(4.47)\end{array}$ & $\begin{array}{r}-27.20^{*} \\
(4.69)\end{array}$ & $\begin{aligned} & 5.63^{+} \\
&(2.82)\end{aligned}$ & $\begin{array}{r}-2.78 \\
(2.92)\end{array}$ & $\begin{array}{l}24.36^{*} \\
(4.69)\end{array}$ \\
\hline \multicolumn{13}{|l|}{ Men $\quad(N=14070)$} \\
\hline Labor regulation & $\begin{array}{c}0.12 \\
(0.51)\end{array}$ & $\begin{array}{c}1.29 * \\
(0.29)\end{array}$ & $\begin{array}{r}-0.18 \\
(0.45)\end{array}$ & $\begin{array}{r}-1.23 \\
(0.65)\end{array}$ & $\begin{array}{c}0.16 \\
(0.65)\end{array}$ & $\begin{array}{c}1.61 * \\
(0.32)\end{array}$ & $\begin{array}{r}-0.19 \\
(0.53)\end{array}$ & $\begin{array}{c}-1.57^{+} \\
(0.66)\end{array}$ & $\begin{array}{c}0.50 \\
(0.55)\end{array}$ & $\begin{array}{c}1.97^{*} \\
(0.39)\end{array}$ & $\begin{array}{r}-0.74 \\
(0.54)\end{array}$ & $\begin{array}{r}-1.72^{+} \\
(0.68)\end{array}$ \\
\hline Poor $(=1)$ & & & & & $\begin{array}{c}7.52^{*} \\
(1.73)\end{array}$ & $\begin{array}{c}-5.10^{*} \\
(0.98)\end{array}$ & $\begin{array}{c}20.31^{*} \\
(1.61)\end{array}$ & $\begin{array}{r}-22.73^{*} \\
(1.70)\end{array}$ & $\begin{array}{c}8.36^{*} \\
(1.60)\end{array}$ & $\begin{array}{c}-6.07 * \\
(0.97)\end{array}$ & $\begin{array}{l}21.44^{*} \\
(1.65)\end{array}$ & $\begin{array}{r}-23.74^{*} \\
(1.57)\end{array}$ \\
\hline Log district consumption p. c. & & & & & $\begin{array}{c}-6.61 \\
(3.53)\end{array}$ & $\begin{array}{c}-2.72 \\
(2.04)\end{array}$ & $\begin{array}{c}7.95^{+} \\
(3.24)\end{array}$ & $\begin{array}{c}1.39 \\
(4.14)\end{array}$ & $\begin{array}{c}-6.30 \\
(3.52)\end{array}$ & $\begin{array}{c}-1.94 \\
(2.21)\end{array}$ & $\begin{array}{c}6.16 \\
(3.49)\end{array}$ & $\begin{array}{c}2.07 \\
(4.41)\end{array}$ \\
\hline District unionization $\times 10$ & & & & & $\begin{array}{c}1.70^{+} \\
(0.72)\end{array}$ & $\begin{array}{c}-1.22^{*} \\
(0.47)\end{array}$ & $\begin{array}{c}2.59^{*} \\
(0.61)\end{array}$ & $\begin{array}{r}-3.08^{*} \\
(0.87)\end{array}$ & $\begin{array}{c}0.07 \\
(1.24)\end{array}$ & $\begin{array}{c}1.23^{+} \\
(0.61)\end{array}$ & $\begin{array}{r}-0.40 \\
(0.91)\end{array}$ & $\begin{array}{c}-0.90 \\
(1.31)\end{array}$ \\
\hline Dist. gov. employment $\times 10$ & & & & & $\begin{array}{r}-10.71^{*} \\
(3.64)\end{array}$ & $\begin{array}{c}3.94^{+} \\
(1.59)\end{array}$ & $\begin{array}{r}-17.46^{*} \\
(2.68)\end{array}$ & $\begin{array}{l}24.23^{*} \\
(3.12)\end{array}$ & $\begin{array}{r}-8.13^{+} \\
(3.44)\end{array}$ & $\begin{array}{r}-0.24 \\
(1.73)\end{array}$ & $\begin{array}{c}-12.42^{*} \\
(2.66)\end{array}$ & $\begin{array}{l}20.78^{*} \\
(3.25)\end{array}$ \\
\hline 6 metro areas $(=1)$ & & & & & $\begin{array}{c}-3.89 \\
(2.65)\end{array}$ & $\begin{array}{r}-4.64^{*} \\
(1.17)\end{array}$ & $\begin{array}{c}-4.28^{+} \\
(2.13)\end{array}$ & $\begin{array}{l}12.81^{*} \\
(3.10)\end{array}$ & $\begin{array}{c}-4.77^{+} \\
(2.06)\end{array}$ & $\begin{array}{c}-2.84^{+} \\
(1.28)\end{array}$ & $\begin{array}{c}-5.39^{+} \\
(2.09)\end{array}$ & $\begin{array}{l}12.99^{*} \\
(2.96)\end{array}$ \\
\hline $\begin{array}{l}10 \text { industries' shares on } \\
\text { labor-force }\end{array}$ & - & - & - & - & - & - & - & - & Yes & Yes & Yes & Yes \\
\hline Casts \& religions & Yes & Yes & Yes & Yes & Yes & Yes & Yes & Yes & Yes & Yes & Yes & Yes \\
\hline 5-year cohorts & Yes & Yes & Yes & Yes & Yes & Yes & Yes & Yes & Yes & Yes & Yes & Yes \\
\hline
\end{tabular}

$F$-test labor regulation $=0$

Women: $F(3,2471)=$

NOTE.-Reported estimates are marginal effects from multinomial logit models evaluated at means of explanatory variables, separately for men and women, expressed in percents. Sample: urban population between 18 and 65 years. For variable definitions see Table A6 in the Appendix. Standard errors clustered on households are in parentheses: ${ }^{+} p<0.05, * p<0.01$.

${ }^{1}$ Outcome variable work type takes on value 0 (Agri.) if respondent works in agriculture, 1 (Busi.) if she works in a family business, 2 (Nonag.) if she works as a non-agricultural wage laborer, and 3 (Salary) if she has a salaried position. 
logit models with the same control variables as in Table 4. The results suggest that women are more likely to work in agriculture as a result of increased labor regulation, while men are more likely to be self-employed. As coefficients on poverty indicators and district consumption per capita variables in Tables 4 and 5 suggest, poor women (and men) are more likely to be economically active and work in agriculture. If the poor have a stronger attachment to the labor market, it is possible to interpret the results in Table 5 so thatnon-agricultural—job market opportunities for women with weaker attachments to the labor force are diminished as a result of labor regulation. At the same time, men seem to be able to compensate for fewer employment opportunities by self-employment.

To summarize, results in this section suggest that women's economic activity is negatively affected by labor regulation mainly because of fewer employment opportunities. While men also face fewer jobs, this effect is substantially smaller, and their overall participation is unaffected as they move into self-employment. It is plausible to contend that labor regulation results in fewer jobs for individuals who are not fully committed to the labor market or are marginal in some other sense. Taking into account lower female participation, the proportional effects of labor regulation on the female labor force are spectacular.

\subsection{Wages and the Gender Wage Gap}

This section explores the relationship between labor regulation, wages and gender-wage differences. As noted above, the equalizing hypothesis predicts that regulatory measures and institutions should compress the wage structure and with it the gender wage gap. Figure 1 indeed suggests that there is a positive relationship between labor regulation and wages, as well as between labor regulation and the gender-wage ratio. To probe this relationship econometrically, I run wage regressions in the following form:

$$
y_{i}=\beta_{0}+r_{i} \beta_{1}+\mathbf{x}_{\mathbf{i}}^{\prime} \beta_{\mathbf{2}}+w_{i}\left(\beta_{3}+r_{i} \beta_{4}+\mathbf{x}_{\mathbf{i}}^{\prime} \beta_{\mathbf{4}}\right)+e_{i},
$$


where $y_{i}$ is the log of hourly wages; $r_{i}$ is the labor regulation measure for $i$ 's state; $\mathbf{x}_{\mathbf{i}}$ is a vector of control variables; $w_{i}$ is the dummy for women; and $e_{i}$ is the disturbance term. $\beta_{1}$ captures the effect of labor regulation on male wages and $\beta_{3}$ captures the gender wage gap. The main coefficient of interest is $\beta_{4}$, which captures changes in women's relative wages that are related to changes in labor regulation.

In light of the findings in the previous section, one must immediately note that selection into the labor force is of legitimate concern if correlated with wages. Since differences in labor participation across regulatory regimes are likely to be accounted for by marginal workers, coefficients $\beta_{4}$ and $\beta_{2}$ will be picking up the differences in labor force productivity across states and thus should be only interpreted as the upper-bound of potential effects of labor regulation on wages.

Specification (1) in Table 6 reports raw estimates confirming Figure 1: male wages are higher in states with more labor regulation; women receive an additional increase above that. However, adding dummies for castes, religions, and birth cohorts in specification (2) results in the coefficient on labor regulation (i.e. the effect on men's wages) losing most of its value as well as statistical significance. ${ }^{18}$

Specification (3) adds controls for years of education and potential experience, and specification (4) allows women-specific coefficients on these controls. All coefficients in specification (3) have correct signs and sensible magnitudes. Estimates in specification (4) suggest that women get higher returns from education and have less concave wage profiles. In both specifications, however, the coefficient on the interaction between labor regulation and the women's dummy loses almost half of its value and is no longer statistically significant. This suggests that smaller gender differences in pay in states with more regulated labor markets are due to cross-state differences in productivity characteristics, which is consistent with selection effects. Adding controls in specification (5) for job characteristics (dummies for working more than 240 days, having permanent worker status, and for government workers), district-level unionization, and government employment, changes results little, except that the effect of labor regulation on male wages becomes

\footnotetext{
${ }^{18}$ Unreported results revealed that almost all of this change occurs as result of adding castes and religions.
} 
Table 6

Labor Regulation and the Gender Wage Gap

\begin{tabular}{|c|c|c|c|c|c|c|c|}
\hline Outcome: Log Hourly Wage & (1) & (2) & (3) & (4) & (5) & (6) & (7) \\
\hline Woman $(=1)$ & $\begin{array}{c}-.507^{*} \\
(.033)\end{array}$ & $\begin{array}{c}-.499 * \\
(.031)\end{array}$ & $\begin{array}{r}-.303^{*} \\
(.026)\end{array}$ & $\begin{array}{c}-.234^{*} \\
(.085)\end{array}$ & $\begin{array}{c}-.241^{*} \\
(.079)\end{array}$ & $\begin{array}{r}-.166^{+} \\
(.076)\end{array}$ & $\begin{array}{r}-.233^{*} \\
(.074)\end{array}$ \\
\hline Labor regulation & $\begin{array}{c}.032^{+} \\
(.013)\end{array}$ & $\begin{array}{c}.012 \\
(.011)\end{array}$ & $\begin{array}{c}.012 \\
(.009)\end{array}$ & $\begin{array}{c}.012 \\
(.009)\end{array}$ & $\begin{array}{c}.002 \\
(.007)\end{array}$ & $\begin{array}{c}.002 \\
(.007)\end{array}$ & $\begin{array}{c}.002 \\
(.007)\end{array}$ \\
\hline Labor regulation× woman $(=1)$ & $\begin{array}{c}.042^{+} \\
(.021)\end{array}$ & $\begin{array}{c}.039^{+} \\
(.020)\end{array}$ & $\begin{array}{c}.024 \\
(.017)\end{array}$ & $\begin{array}{c}.022 \\
(.017)\end{array}$ & $\begin{array}{c}.020 \\
(.016)\end{array}$ & $\begin{array}{c}.011 \\
(.014)\end{array}$ & $\begin{array}{c}.006 \\
(.014)\end{array}$ \\
\hline \multicolumn{8}{|l|}{ Woman $(=1) \times$} \\
\hline years of education & & & & $\begin{array}{c}.017^{*} \\
(.004)\end{array}$ & $\begin{array}{c}.003 \\
(.005)\end{array}$ & $\begin{array}{c}-.005 \\
(.005)\end{array}$ & $\begin{array}{r}-.003 \\
(.004)\end{array}$ \\
\hline potential experience & & & & $\begin{array}{c}-.017 * \\
(.005)\end{array}$ & $\begin{array}{r}-.018^{*} \\
(.004)\end{array}$ & $\begin{array}{c}-.014 * \\
(.004)\end{array}$ & $\begin{array}{r}-.012 * \\
(.004)\end{array}$ \\
\hline$(\text { potential experience })^{2} / 100$ & & & & $\begin{array}{c}.003^{*} \\
(.001)\end{array}$ & $\begin{array}{c}.003^{*} \\
(.001)\end{array}$ & $\begin{array}{c}.002 * \\
(.001)\end{array}$ & $\begin{array}{c}.002^{+} \\
(.001)\end{array}$ \\
\hline works $\geq 240$ days $(=1)$ & & & & & $\begin{array}{c}.035 \\
(.037)\end{array}$ & $\begin{array}{c}.038 \\
(.037)\end{array}$ & $\begin{array}{c}.041 \\
(.036)\end{array}$ \\
\hline permanent worker $(=1)$ & & & & & $\begin{array}{c}.104 \\
(.087)\end{array}$ & $\begin{array}{c}.092 \\
(.078)\end{array}$ & $\begin{array}{c}.107 \\
(.076)\end{array}$ \\
\hline government worker $(=1)$ & & & & & $\begin{array}{l}.145 \\
(.085)\end{array}$ & $\begin{array}{l}.145 \\
(.078)\end{array}$ & $\begin{array}{c}.138 \\
(.075)\end{array}$ \\
\hline district unionization $\times 10$ & & & & & $\begin{array}{r}-.033 \\
(.020)\end{array}$ & $\begin{array}{c}-.028 \\
(.018)\end{array}$ & $\begin{array}{r}-.028 \\
(.018)\end{array}$ \\
\hline dist. gov. employment $\times 10$ & & & & & $\begin{array}{c}.136^{+} \\
(.053)\end{array}$ & $\begin{array}{c}.097 \\
(.052)\end{array}$ & $\begin{array}{c}.108^{+} \\
(.051)\end{array}$ \\
\hline Years of education & & & $\begin{array}{c}.088^{*} \\
(.005)\end{array}$ & $\begin{array}{c}.083^{*} \\
(.005)\end{array}$ & $\begin{array}{c}.050^{*} \\
(.005)\end{array}$ & $\begin{array}{c}.045^{*} \\
(.005)\end{array}$ & $\begin{array}{l}.032^{*} \\
(.004)\end{array}$ \\
\hline Potential experience & & & $\begin{array}{c}.040^{*} \\
(.006)\end{array}$ & $\begin{array}{c}.046^{*} \\
(.006)\end{array}$ & $\begin{array}{c}.026^{*} \\
(.005)\end{array}$ & $\begin{array}{c}.024^{*} \\
(.005)\end{array}$ & $\begin{array}{c}.023^{*} \\
(.005)\end{array}$ \\
\hline$(\text { Potential experience })^{2} / 100$ & & & $\begin{array}{c}-.006^{*} \\
(.001)\end{array}$ & $\begin{array}{c}-.007^{*} \\
(.001)\end{array}$ & $\begin{array}{c}-.004^{*} \\
(.001)\end{array}$ & $\begin{array}{c}-.003 * \\
(.001)\end{array}$ & $\begin{array}{r}-.004^{*} \\
(.001)\end{array}$ \\
\hline Works $\geq 240$ days $(=1)$ & & & & & $\begin{array}{c}.063^{*} \\
(.018)\end{array}$ & $\begin{array}{l}.042^{+} \\
(.019)\end{array}$ & $\begin{array}{c}.041^{+} \\
(.019)\end{array}$ \\
\hline Permanent worker $(=1)$ & & & & & $\begin{array}{c}.424^{*} \\
(.031)\end{array}$ & $\begin{array}{l}.403^{*} \\
(.030)\end{array}$ & $\begin{array}{l}.344^{*} \\
(.028)\end{array}$ \\
\hline Government worker $(=1)$ & & & & & $\begin{array}{c}.393^{*} \\
(.033)\end{array}$ & $\begin{array}{c}.347^{*} \\
(.031)\end{array}$ & $\begin{array}{r}.345^{*} \\
(.029)\end{array}$ \\
\hline District unionization $\times 10$ & & & & & $\begin{array}{c}.039 * \\
(.009)\end{array}$ & $\begin{array}{l}.041^{*} \\
(.009)\end{array}$ & $\begin{array}{l}.044^{*} \\
(.009)\end{array}$ \\
\hline Dist. gov. employment $\times 10$ & & & & & $\begin{array}{c}.138 * \\
(.033)\end{array}$ & $\begin{array}{l}.117^{*} \\
(.032)\end{array}$ & $\begin{array}{l}.116^{*} \\
(.030)\end{array}$ \\
\hline Constant & $\begin{array}{l}2.707^{*} \\
(.020)\end{array}$ & $\begin{array}{l}3.407^{*} \\
(.046)\end{array}$ & $\begin{array}{l}1.682^{*} \\
(.196)\end{array}$ & $\begin{array}{l}1.659^{*} \\
(.194)\end{array}$ & $\begin{array}{l}1.719^{*} \\
(.174)\end{array}$ & $\begin{array}{l}1.589^{*} \\
(.171)\end{array}$ & $\begin{array}{c}2.297^{*} \\
(.273)\end{array}$ \\
\hline 2 digit occupations & - & - & - & - & - & - & Yes \\
\hline 2 digit industries & - & - & - & - & - & Yes & Yes \\
\hline Casts \& religions & - & Yes & Yes & Yes & Yes & Yes & Yes \\
\hline 5-year cohorts & - & Yes & Yes & Yes & Yes & Yes & Yes \\
\hline$N$ & 12567 & 12567 & 12526 & 12526 & 12526 & 11887 & 11882 \\
\hline Adjusted $\mathrm{R}^{2}$ & .07 & .22 & .40 & .40 & .54 & .57 & .60 \\
\hline
\end{tabular}


zero. The last two specifications add dummies for 2-digit industries and occupations. As a result, the coefficient on the interaction between labor regulation and the women's dummy drops further and remains insignificant.

I interpret these findings as suggesting that there is no evidence of a positive effect of labor regulation on wages and gender-wage differences; which is in line with, and complements, results in Besley and Burgess (2004) and Ahsan and Pagés (2009). Small gender-wage differences in more regulated labor markets disappear once human capital and job characteristics are controlled for, suggesting that this effect may partly be spurious due to lower economic activity and a selection induced by the labor regulation itself. ${ }^{19}$

\subsection{Auxiliary Evidence-Women's Say and Sex Ratio}

Because a woman's labor market prospects may indirectly influence her position in the household, I investigate whether cross-state differences in women's say, seen in Table 3 , are related to labor regulation. IHDS asks all ever-married women who are between 15 and 49 years of age a battery of questions exploring gender relations within households. Specifically, each eligible woman is asked whether she or someone else decides: What to cook on a daily basis; whether to buy an expensive item such as a TV or fridge; how many children to have; what to do if a child falls sick; and who should your children marry? From this data I construct a "women most-say" index ranging from zero to five, as a count of affirmative answers, indicating a woman's position in the household. ${ }^{20}$

Table 7 reports the results from tobit models estimated on an urban as well as a rural population, where the women most-say index is the outcome. Women's say seems to be negatively related to labor regulation both in rural and urban areas, although estimates are tighter in urban areas. This may be a direct result of a higher share of household income going through women's hands. It is also quite plausible that the women's labor market opportunities define her outside (of marriage) options, influencing her relative bargaining

\footnotetext{
${ }^{19}$ One may still counter that labor regulation may induce higher investments in human capital and influence occupational differences between men and women. In that case, specifications that do not control for these variables may be preferable. Nonetheless, selection into labor force would still be biasing the estimates of the effects of labor regulation on wages upwards.

${ }^{20}$ See Sen, Rastogi, and Vanneman (2006) who employ similar index.
} 
Table 7

Women's Say

\begin{tabular}{|c|c|c|c|c|c|c|c|c|}
\hline \multirow{2}{*}{$\begin{array}{l}\text { Outcome: Woman } \\
\text { Most-Say Index }(=0-5)\end{array}$} & \multicolumn{4}{|c|}{ Rural } & \multicolumn{4}{|c|}{ Urban } \\
\hline & (1) & (2) & (3) & (4) & (5) & (6) & (7) & (8) \\
\hline Labor regulation & $\begin{array}{c}-0.063^{+} \\
(0.029)\end{array}$ & $\begin{array}{c}-0.069^{+} \\
(0.030)\end{array}$ & $\begin{array}{c}-0.059^{+} \\
(0.025)\end{array}$ & $\begin{array}{c}-0.098^{*} \\
(0.022)\end{array}$ & $\begin{array}{c}-0.080^{*} \\
(0.019)\end{array}$ & $\begin{array}{r}-0.048^{*} \\
(0.018)\end{array}$ & $\begin{array}{c}-0.049^{*} \\
(0.017)\end{array}$ & $\begin{array}{c}-0.056^{*} \\
(0.020)\end{array}$ \\
\hline Poor (=1) & & & $\begin{array}{r}-0.069 \\
(0.070)\end{array}$ & $\begin{array}{l}-0.001 \\
(0.067)\end{array}$ & & & $\begin{array}{c}-0.024 \\
(0.058)\end{array}$ & $\begin{array}{r}-0.014 \\
(0.057)\end{array}$ \\
\hline $\begin{array}{l}\text { Log district } \\
\text { consumption p. c. }\end{array}$ & & & $\begin{array}{c}0.254 \\
(0.233)\end{array}$ & $\begin{array}{c}0.144 \\
(0.232)\end{array}$ & & & $\begin{array}{c}0.299^{*} \\
(0.100)\end{array}$ & $\begin{array}{c}0.122 \\
(0.100)\end{array}$ \\
\hline $\begin{array}{l}\text { Distict government } \\
\text { employment } \times 10\end{array}$ & & & $\begin{array}{c}0.199 \\
(0.288)\end{array}$ & $\begin{array}{c}0.132 \\
(0.263)\end{array}$ & & & $\begin{array}{c}-0.187^{+} \\
(0.075)\end{array}$ & $\begin{array}{c}-0.158^{+} \\
(0.080)\end{array}$ \\
\hline $\begin{array}{l}\text { District } \\
\text { unionization } \times 10\end{array}$ & & & $\begin{array}{c}0.035 \\
(0.074)\end{array}$ & $\begin{array}{c}-0.033 \\
(0.076)\end{array}$ & & & $\begin{array}{c}0.048 \\
(0.032)\end{array}$ & $\begin{array}{c}0.039 \\
(0.034)\end{array}$ \\
\hline Constant & $\begin{array}{c}0.590^{*} \\
(0.040)\end{array}$ & $\begin{array}{l}0.349 * \\
(0.117)\end{array}$ & $\begin{array}{c}-1.379 \\
(1.416)\end{array}$ & $\begin{array}{c}7.220 \\
(3.949)\end{array}$ & $\begin{array}{l}0.934^{*} \\
(0.030)\end{array}$ & $\begin{array}{l}0.823^{*} \\
(0.079)\end{array}$ & $\begin{array}{c}-1.158 \\
(0.676)\end{array}$ & $\begin{array}{l}16.427 * \\
(3.664)\end{array}$ \\
\hline $\begin{array}{l}10 \text { industries' shares on } \\
\text { labor-force }\end{array}$ & - & - & - & Yes & - & - & - & Yes \\
\hline Casts \& religions & - & Yes & Yes & Yes & - & Yes & Yes & Yes \\
\hline 5-year cohorts & - & Yes & Yes & Yes & - & Yes & Yes & Yes \\
\hline$N$ & 23184 & 23184 & 23184 & 23184 & 12481 & 12481 & 12481 & 12481 \\
\hline
\end{tabular}

NOTE.-Reported estimates are coefficients from tobit models (lower bound=0, upper bound=5). The "women most-say" index counts the number of cases in which the respondent identified herself as the one who has the most say in the following five decisions: What to cook on a daily basis; whether to buy an expensive item such as a TV or fridge; how many children to have; what to do if a child falls sick; and who should your children marry? The respondent is the "eligible woman", i.e. "an ever-married woman between the ages of 15 and 49 " in a household. Sample: all households. For variable definitions see Table A6 in the Appendix. Standard errors are in parentheses: ${ }^{+} p<0.05,{ }^{*} p<0.01$.

power and esteem; thus, the opportunity costs of her household production may induce husbands to "buy off" her household time. ${ }^{21}$

If labor regulation affects women's (relative) well-being and outlook, one might expect that — to the extent it is possible—-some women could migrate into areas where conditions are perceived as better. Alternatively, some parents with daughters may make such decisions. In addition, selective abortions are now common in India as ultrasound has become more available in recent years (Jha et al. 2011). ${ }^{22}$ Relative job market prospects of boys and girls may influence the relative "value" of having a boy or girl and therefore abortion decisions. In each case, one would expect labor regulation to have an impact on the sex ratio in the population.

Table 8 reports the marginal effects from logit regressions, where the outcome is the respondents' sex. There is a consistently negative and statistically significant effect of

\footnotetext{
${ }^{21}$ For recent evidence along these lines see Aizer (2010).

22 The estimates of the conditional sex ratio for second order births when the firstborn was a girl in 1990 and 2005 are 906 and 836 girls per 1000 boys, respectively (Jha et al. 2011). This translates—based on their estimates -into 20 to 60 million selectively aborted girls in 2005. See also Bharadwaj and Lakdawala (2013).
} 
Table 8

Women in the Population

\begin{tabular}{|c|c|c|c|c|c|c|c|c|}
\hline \multirow[b]{2}{*}{ Outcome: Woman $(=1)$} & \multicolumn{4}{|c|}{ Rural } & \multicolumn{4}{|c|}{ Urban } \\
\hline & (1) & (2) & (3) & (4) & (5) & (6) & (7) & (8) \\
\hline Labor regulation & $\begin{array}{c}0.113 \\
(0.122)\end{array}$ & $\begin{array}{c}0.133 \\
(0.124)\end{array}$ & $\begin{array}{c}0.073 \\
(0.120)\end{array}$ & $\begin{array}{c}-0.071 \\
(0.133)\end{array}$ & $\begin{array}{c}-0.358^{*} \\
(0.099)\end{array}$ & $\begin{array}{c}-0.329^{*} \\
(0.102)\end{array}$ & $\begin{array}{c}-0.371^{*} \\
(0.105)\end{array}$ & $\begin{array}{r}-0.413^{*} \\
(0.122)\end{array}$ \\
\hline Age $<18$ & & $\begin{array}{c}-2.382^{*} \\
(0.890)\end{array}$ & $\begin{array}{r}-2.521^{*} \\
(0.891)\end{array}$ & $\begin{array}{r}-2.564^{*} \\
(0.901)\end{array}$ & & $\begin{array}{r}-1.008 \\
(0.789)\end{array}$ & $\begin{array}{r}-1.126 \\
(0.793)\end{array}$ & $\begin{array}{r}-1.114 \\
(0.794)\end{array}$ \\
\hline Age $>65$ & & $\begin{array}{c}-3.231^{+} \\
(1.474)\end{array}$ & $\begin{array}{c}-3.225^{+} \\
(1.470)\end{array}$ & $\begin{array}{c}-3.246^{+} \\
(1.469)\end{array}$ & & $\begin{array}{c}2.861^{+} \\
(1.319)\end{array}$ & $\begin{array}{c}2.723^{+} \\
(1.321)\end{array}$ & $\begin{array}{r}2.694^{+} \\
(1.322)\end{array}$ \\
\hline Poor $(=1)$ & & & $\begin{array}{r}2.031^{*} \\
(0.448)\end{array}$ & $\begin{array}{l}2.054^{*} \\
(0.433)\end{array}$ & & & $\begin{array}{c}1.871^{*} \\
(0.438)\end{array}$ & $\begin{array}{r}1.933^{*} \\
(0.443)\end{array}$ \\
\hline $\begin{array}{l}\text { Log district } \\
\text { consumption p. c. }\end{array}$ & & & $\begin{array}{c}0.372 \\
(0.932)\end{array}$ & $\begin{array}{c}-0.075 \\
(0.981)\end{array}$ & & & $\begin{array}{c}0.275 \\
(0.689)\end{array}$ & $\begin{array}{r}-0.402 \\
(0.751)\end{array}$ \\
\hline $\begin{array}{l}\text { District } \\
\text { unionization } \times 10\end{array}$ & & & $\begin{array}{c}-0.083 \\
(0.213)\end{array}$ & $\begin{array}{c}-0.228 \\
(0.261)\end{array}$ & & & $\begin{array}{c}0.564^{*} \\
(0.156)\end{array}$ & $\begin{array}{r}0.512^{+} \\
(0.208)\end{array}$ \\
\hline $\begin{array}{l}\text { Distict government } \\
\text { employment } \times 10\end{array}$ & & & $\begin{array}{c}0.701 \\
(1.153)\end{array}$ & $\begin{array}{c}1.234 \\
(1.093)\end{array}$ & & & $\begin{array}{c}-0.401 \\
(0.536)\end{array}$ & $\begin{array}{c}0.143 \\
(0.604)\end{array}$ \\
\hline $\begin{array}{l}10 \text { industries' shares on } \\
\text { labor-force }\end{array}$ & - & - & - & Yes & - & - & - & Yes \\
\hline Casts \& religions & - & Yes & Yes & Yes & - & Yes & Yes & Yes \\
\hline 5-year cohorts & - & Yes & Yes & Yes & - & Yes & Yes & Yes \\
\hline$N$ & 124538 & 124538 & 124538 & 124538 & 60955 & 60955 & 60955 & 60955 \\
\hline
\end{tabular}

labor regulation on the presence of women in urban areas. A one point increase in the labor regulation measure is associated with about a 0.35 percentage point smaller share of women in population, or about a $0.7 \%$ smaller female population $(0.0035 / 0.5)$. There is no significant effect in rural areas, although positive coefficients-except in specification (4) - may suggest that women are less likely to migrate out of rural areas in states with more labor regulation. When interpreting these estimates it is worth noting that there are factors mitigating the potential effects of labor regulation on migration, namely marriage markets and the generally low geographic mobility in India (Munshi and Rosenzweig 2009; Topalova 2010). These findings also suggest that the effects of labor regulation on women's employment in Table 4 are conservative.

\subsection{Endogeneity of State Amendments}

As mentioned in Section 3, there are reasons to be worried about the precision of the labor regulation measure and resulting attenuation bias. One may be also legitimately concerned about the direction of causality in the relationship between labor regulation and 
labor market outcomes. Changes in labor regulation hardly occur randomly. Rather, they are introduced and implemented via political processes and may be influenced by interest groups. It is possible that some changes in labor regulation may result from variability in outcomes that influence the costs and benefits of passing (repealing) individual amendments. In that case, our estimates of these effects would be too high. Using an exogenous source of variation in labor regulation and instrumenting labor regulation measures with it would help to address this concern.

Besley and Burgess (2004) observe that most changes in labor regulation took place after 1977, following the declaration of a state of emergency. The Congress Party lost its dominance over state governments, which led to a series of switches in political control at the state level. Thus, early state-level changes in the 1947 Industrial Disputes Act can be associated with these political changes. They suggest two variables for capturing the initial conditions that triggered political changes and their direction: pre-1977 unionization and historical patterns of land tenure captured by the fraction of districts in each state, which had non-landlord-based revenue collection systems. Those areas tend to have larger concentrations of regional parties — competitors of the left wing Congress party-making them more conservative with respect to labor regulation. I use these two variables as instruments for labor regulation measures restricted to amendments that took place after 1977.

The first three columns of Table 9 report the results from OLS regressions of labor regulation measures from Table 1 on these two instruments using a sample of the 15 states for which data are available. ${ }^{23}$ The two labor regulation measures based on amendments are fairly well predicted by the instruments, as suggested by relatively high coefficients of determination reported at the bottom. Comparing the coefficients in columns (1) and (2) in Table 9 with column (7) of Table VI in Besley and Burgess (2004), the signs are identical although the magnitudes in are somewhat higher. ${ }^{24}$ Pre-1977 unionization is, not surprisingly, positively related to labor regulation, while the proportion of districts under

\footnotetext{
${ }^{23}$ Pre-1977 data on unionization are missing for the state of Jammu \& Kasmir.

${ }^{24}$ Besley and Burgess (2004) run a panel data model in which both instruments interact with a post-1977 dummy so that coefficients are not directly comparable.
} 
non-landlord agricultural tax systems is negatively correlated with it. In the case of the combined labor regulation measure, the relationship between instruments and the measure is much weaker, which is confirmed by an $F$-test of the two coefficients. I therefore report the results for all three definitions of labor regulation measures.

Columns (6) through (9) report the marginal effects of instrumented labor regulation measures from IV probit models run separately for men and women. Apart from instrumentation, specifications are identical to those in columns (1) through (3) in Table 4. For women, the results in columns (4) and (5) are quite similar across the definitions of labor regulation and are qualitatively similar to the estimates in Table 4. Once industrial structure is controlled for in specification (6), estimates switch signs in two cases and are no longer statistically significant; similar changes take place in the case of men in specification (9). One explanation for this may be that the instrument (pre-1977 unionization) may be correlated with the current industrial structure. More importantly, the instruments may influence the industrial structure via regulation of labor markets. I suggest estimates without the industrial structure are preferable. In sum, I find these results to support the main evidence presented above.

\subsection{Robustness Checks}

This section presents the estimates of alternative specifications in order to check the sensitivity of our findings. Table A2 in the Appendix reports the results of robustness checks for our estimated effects of labor regulation on the participation in the labor force and employment; base results from Table 4 are repeated at the top. I first drop West Bengal as it has passed the largest number of amendments, making it the most pro-worker state. Next, I restrict the sample to non-metropolitan areas. I also replace the combined laborregulation measure by one based only on amendments to the 1947 IDA. Then, because most changes in labor regulation occurred in the aftermath of the 1977 state of emergency, I include pre-1977 state characteristics to check for the possibility that results may be 


\section{Table 9}

\section{Instrumenting Labor Regulation Measures}

\begin{tabular}{|c|c|c|c|c|c|c|c|c|c|}
\hline \multirow[t]{4}{*}{ Outcome (Method): } & \multicolumn{3}{|c|}{ Labor Regulation (OLS) } & \multicolumn{6}{|c|}{ Anyjob (=1) (IV Probit) } \\
\hline & \multicolumn{2}{|c|}{ Amendments } & \multirow{3}{*}{$\begin{array}{c}\text { Combined } \\
\text { Measure } \\
\text { (3) }\end{array}$} & \multicolumn{6}{|c|}{ Coefficients on Labor Regulation Variable } \\
\hline & $(1977-1992)$ & $(1977-2004)$ & & & & & & & \\
\hline & (1) & (2) & & (4) & $(5)$ & (6) & (7) & (8) & (9) \\
\hline $\begin{array}{l}\text { Mean pre-1977 } \\
\text { unionization }\end{array}$ & $\begin{array}{l}0.10^{+} \\
(0.04)\end{array}$ & $\begin{array}{l}0.10^{+} \\
(0.04)\end{array}$ & $\begin{array}{c}0.01 \\
(0.06)\end{array}$ & & & & & & \\
\hline $\begin{array}{l}\text { Mean nonlandlord } \\
\text { tenure }\end{array}$ & $\begin{array}{c}-2.23^{*} \\
(0.65)\end{array}$ & $\begin{array}{c}-1.92^{+} \\
(0.72)\end{array}$ & $\begin{array}{c}-1.48 \\
(1.01)\end{array}$ & & & & & & \\
\hline $\begin{array}{l}\text { Labor regulation } \\
\text { measures }\end{array}$ & & & & \multicolumn{3}{|c|}{ Women } & \multicolumn{3}{|c|}{ Men } \\
\hline $\begin{array}{l}\text { Amendments } \\
(1977-1992)\end{array}$ & & & & $\begin{array}{r}-2.36^{*} \\
(0.56)\end{array}$ & $\begin{array}{c}-1.97^{*} \\
(0.71)\end{array}$ & $\begin{array}{l}1.00 \\
(0.98)\end{array}$ & $\begin{array}{c}-0.76^{+} \\
(0.36)\end{array}$ & $\begin{array}{r}-0.65 \\
(0.41)\end{array}$ & $\begin{array}{c}0.43 \\
(0.55)\end{array}$ \\
\hline $\begin{array}{l}\text { Amendments } \\
(1977-2004)\end{array}$ & & & & $\begin{array}{c}-2.46^{*} \\
(0.58)\end{array}$ & $\begin{array}{c}-2.08^{*} \\
(0.76)\end{array}$ & $\begin{array}{l}1.31 \\
(0.87)\end{array}$ & $\begin{array}{c}-0.85^{+} \\
(0.37)\end{array}$ & $\begin{array}{r}-0.73 \\
(0.44)\end{array}$ & $\begin{array}{c}0.32 \\
(0.49)\end{array}$ \\
\hline Combined measure & & & & $\begin{array}{c}-2.03^{+} \\
(0.98)\end{array}$ & $\begin{array}{c}-2.37^{*} \\
(0.89)\end{array}$ & $\begin{array}{c}-0.61 \\
(1.42)\end{array}$ & $\begin{array}{c}0.58 \\
(0.59)\end{array}$ & $\begin{array}{c}0.59 \\
(0.52)\end{array}$ & $\begin{array}{c}0.81 \\
(0.75)\end{array}$ \\
\hline$F$-test instruments & 8.56 & 5.84 & 1.09 & & & & & & \\
\hline Prob $>F$ & $(0.005)$ & $(0.017)$ & $(0.369)$ & & & & & & \\
\hline$R^{2}$ & 0.59 & 0.49 & 0.15 & & & & & & \\
\hline$N$ & 15 & 15 & 15 & & & & & & \\
\hline
\end{tabular}

NOTE.-Reported estimates in columns (4) through (9) are marginal effects from IV probit models evaluated at the means of explanatory variables, separately for men and women, expressed in percents. Labor regulation measures match those in Table 1 except that amendments are restricted to those enacted after 1977. Data on mean pre-1977 unionization and mean non-landlord tenure are from Besley and Burgess (2004). Specifications (4) through (6) and (7) through (9) are identical to specifications (1) through (3) in Table 4. Sample: urban population between 18 and 65 years. Standard errors clustered on households are in parentheses: ${ }^{+} p<0.05,{ }^{*} p<0.01$. 
driven by fixed state characteristics, rather than by labor regulation that occurred later. ${ }^{25}$ To check the possibility that results are driven by a few large states, I change the sampling weights so that they add up to equal state-wise sums. Lastly, I present the estimates for the rural sample.

Looking across specifications (1) through (3), the results are qualitatively and quantitatively similar to the baseline; note how stable the estimates are in specifications (1) and (2). Dropping West Bengal results in larger estimated effects of labor regulation, while effects for the rural sample are slightly smaller. Estimates are more shaky once the structure of industries is controlled for; this may, however, result from the endogeneity in the industrial structure. Results from multinomial logit models reported in columns (4) through (6) also maintain patterns similar to the base estimates.

Table A3 performs the same checks on the wage regressions reported in Table 6 . Here too, results are quite similar to those reported above. While in some cases more robust to the introduction of controls for education and potential experience-specifications (3) and (4) — the effects of labor regulation on gender-wage differences are never statistically significant after the introduction of industry and occupation dummies. Interestingly, pre1977 state characteristics seem to explain differences in male wages correlated with labor regulation. There seems to be some effect of labor regulation on the gender wage gap in the rural population reported at the bottom; I find this a bit puzzling and do not have any strong interpretation of this result.

Similarly, Tables A4 and A5 re-estimate my initial results for women's say within their households and the presence of women in the population. Results for women's say are less stable, particularly for the rural sample; nevertheless, the results for urban areas are always negative and are statistically significant most of the time. This pattern holds for the alternative estimates of effects of labor regulation on the presence of women in the population, as reported in Table A5. While somewhat unstable for the rural sample, results for urban sample are qualitatively similar to the base-line estimates. Interestingly, there

\footnotetext{
25 Pre-1977 state characteristics include the average of Net State Domestic Product (NSDP) per capita 1960-1977, sector shares on NSDP, and the population-share of union members. See note below Table A2 for a more detailed description of the included variables.
} 
is a positive, albeit not statistically significant effect of labor regulation on the female population under the age of 6 , suggesting that the gender selection of children is unrelated to labor regulation. ${ }^{26}$

\section{Discussion}

Results presented in the previous section corroborate the initial patterns suggested in Figure 1: There is a negative relationship between labor regulation and women's labor market participation, particularly employment. The estimated effects of labor regulation on female economic activity are substantively large, especially when the already small share of women participating in Indian labor force is taken into account. A one standard deviation increase in labor regulation measure (1.66) is associated with a $3 \%$ to $4 \%$ decrease in women's economic activity, translating into a $15 \%$ to $18 \%$ decrease in the female labor force. At the same time, I do not find evidence that regulation improves worker's remuneration or diminishes the gender wage gap.

A number of potentially confounding variables have been controlled for. Specifically, lower female participation in more regulated labor markets is not due to individual poverty or district wealth, differences in unionization, government employment, religious or caste effects, or urbanization. The result holds even after controlling for states' industrial structure, which is problematic as it may be directly influenced by the labor regulation itself. I also show that the results are not an artifact of a particular labor regulation measure or historical differences in unionization, output per capita, or its sector structure. The fact that there are no identifiable effects on men's participation (only on employment) makes it less likely that an unobserved economic shock, correlated with labor regulation, and is behind our results. I further show that labor regulation is associated with a higher share of (urban) women working in agriculture, and a higher share of men working in a family business; suggesting that labor regulation negatively affects general employment as well

\footnotetext{
${ }^{26}$ If, however, the correlation between the sex ratio and labor regulation was purely random, this finding would further strengthen those regarding the presence of women in the population and, consequently, the women-specific employment effects of labor regulation.
} 
as job opportunities of marginal workers. These results complement the previous findings of Besley and Burgess (2004) and Ahsan and Pagés (2009) regarding the effects of labor regulation on employment and worker's remuneration.

Labor market opportunities may influence individuals' position at home. I therefore use the gender relations section in the IHDS data to construct an index of women's say within their families and find a negative relationship between labor regulation and women's position in households; an expected result if labor regulation negatively affects women's outside options and the importance of their labor with regard to household income. In addition, I find a negative relationship between labor regulation and the presence of adult women in the population. This finding also suggests that the estimates of the effects of labor regulation on female employment may be attenuated.

The main limitation of this study stems from the cross-sectional nature of the data-the possibility that some unobserved factor correlated with labor regulation and labor market outcomes drives our results cannot be ruled out. While panel data would allow better addressing this issue, no longitudinal dataset containing information on women's labor market activity was available for this study. On the other hand, results presented above are broadly consistent with the longitudinal studies of the effects of labor regulation in India (Besley and Burgess 2004; Ahsan and Pagés 2009; Aghion et al. 2008; Topalova 2007, 2010).

\section{Conclusions}

This paper analyzes the relationship between labor regulation and labor market outcomes of women in India. I proposed two alternative hypotheses of what this relationship might be: The equalizing hypothesis states that labor regulation represents a homogenizing force pushing towards less inequality and should disproportionately help women since they are more often low-wage earners. The exclusion hypothesis states that women's labor market opportunities will deteriorate because low wage workers will be cut off as a result of institutional rigidity. 
My findings support the exclusion hypothesis. I find that labor market rigidity in India negatively affects women's job market opportunities, while it does not improve their wages. Under this interpretation, the institutional barriers to women's employment constitute a failure to make good use of an important source of potentially productive labor and may inhibit the development of women's human capital and restrain the emancipation of women in India. This is an especially dramatic issue in the context of a developing country where attitudes towards women are traditionally disadvantageous, poverty is higher among working women compared to men, and the additional income earned by women likely plays an important role in her outlook and the in well-being of her family. Women in India would benefit from relaxing the regulation of labor and generally better business climate.

A possible direction for future research is to look at how industry deregulation in India (1985 and 1991) has affected women's lives and how these effects have differed across the regimes of labor regulation. Another research opportunity is to look at the potential effects of institutional variation in India on women's human capital investments in the spirit of Geddes, Lueck, and Tennyson (2012). 


\section{References}

Aghion, Philippe, Robin Burgess, Stephen J. Redding, and Fabrizio Zilibotti. 2008. "The unequal effects of liberalization: Evidence from dismantling the License Raj in India." American Economic Review 98:1397-1412.

Ahsan, Ahmad and Carmen Pagés. 2009. "Are all labor regulations equal? Evidence from Indian manufacturing." Journal of Comparative Economics 37:62-75.

Aizer, Anna. 2010. “The gender wage gap and domestic violence.” American Economic Review 100:1847-1859.

Alchian, Armen A. and Reuben A. Kessel. 1962. "Competition, monopoly, and the pursuit of money." In Aspects of labor economics. Princeton: Princeton University Press, $157-184$.

Ashenfelter, Orley and Timothy Hannan. 1986. "Sex discrimination and product market competition: The case of the banking industry." Quarterly Journal of Economics 101:149-173.

Azmat, Ghazala, Maia Guell, and Alan Manning. 2006. "Gender gaps in unemployment rates in OECD countries." Journal of Labor Economics 24:1-37.

Becker, Gary S. 1957. The economics of discrimination. Chicago: University Of Chicago Press.

Besley, Timothy and Robin Burgess. 2004. "Can labor regulation hinder economic performance? Evidence from India.” Quarterly Journal of Economics 119:91-134.

Bharadwaj, Prashant and Leah K. Lakdawala. 2013. "Discrimination begins in the womb: Evidence of sex-selective prenatal investments.” Journal of Human Resources 48 (1):71113.

Bhattacharjea, Aditya. 2006. "Labour market regulation and industrial performance in India: A critical review of the empirical evidence.” Indian Journal of Labour Economics 49:211-232. 
Black, Sandra E. and Elizabeth Brainerd. 2004. "Importing equality? The impact of globalization on gender discrimination." Industrial and Labor Relations Review 57:540_ 559.

Black, Sandra E. and Philip E. Strahan. 2001. "The division of spoils: Rent-sharing and discrimination in a regulated industry." American Economic Review 91:814-831.

Blau, Francine D. and Lawrence M. Kahn. 1992. “The gender earnings gap: Learning from international comparisons." American Economic Review 82:533-538.

_. 1996a. "International differences in male wage inequality: Institutions versus market forces.” Journal of Political Economy 104:791-837.

—. 1996b. "Wage structure and gender earnings differentials: An international comparison.” Economica 63:S29-S62.

— 2003. "Understanding international differences in the gender pay gap." Journal of Labor Economics 21:106-144.

Botero, Juan C., Simeon Djankov, Rafael La Porta, Florencio Lopez-de-Silanes, and Andrei Shleifer. 2004. “The regulation of labor.” Quarterly Journal of Economics 119:1339-1382.

Desai, Sonalde, Reeve Vanneman, and the National Council of Applied Economic Research, New Delhi. 2010. "India human development survey (IHDS), 2005.” Data files, Inter-university Consortium for Political and Social Research, Ann Arbor, MI.

DiNardo, John, Nicole M. Fortin, and Thomas Lemieux. 1996. "Labor market institutions and the distribution of wages, 1973-1992: A semiparametric approach." Econometrica 64:1001-1044.

Fortin, Nicole M. and Thomas Lemieux. 1998. "Rank regressions, wage distributions, and the gender gap.” Journal of Human Resources 33:610-643. 
Geddes, R. Richard, Dean Lueck, and Sharon Tennyson. 2012. "Human capital accumulation and the expansion of women's property rights." Journal of Law and Economics $55: 839-867$.

Goswami, Omkar, David Dollar, A. K. Arun, Srivastava Gantakolla, Vishal More, Arindam Mookherjee, Taye Mengistae, Mary Hallward-Driemier, and Giuseppe Iarossi. 2002. Competitiveness of Indian manufacturing: Results from a firm-level survey. New Delhi and Washington: Confederation of Indian Industry and The World Bank.

Hasan, Rana, Devashish Mitra, and K. V. Ramaswamy. 2007. "Trade reforms, labor regulations, and labor-demand elasticities: Empirical evidence from India." Review of Economics and Statistics 89:466-481.

Jha, Prabhat, Maya A. Kesler, Rajesh Kumar, Faujdar Ram, Usha Ram, Lukasz Aleksandrowicz, Diego G. Bassani, Shailaja Chandra, and Jayant K. Banthia. 2011. "Trends in selective abortions of girls in India: Analysis of nationally representative birth histories from 1990 to 2005 and census data from 1991 to 2011.” The Lancet 377:1921-1928.

Malik, P. L. 2004. Industrial law: Manual of central labour and industrial laws incorporating state amendmentments with rules, regulations and select notifications. 2 vols. 19th ed. Lucknow, India: Eastern Book Company.

Munshi, Kaivan and Mark Rosenzweig. 2009. "Why is mobility in India so low? Social insurance, inequality, and growth." Working Paper no. 14850, the National Bureau of Economic Research, Chicago, MA.

Olivetti, Claudia and Barbara Petrongolo. 2008. "Unequal pay or unequal employment? A cross-country analysis of gender gaps.” Journal of Labor Economics 26:621-654.

Oostendorp, Remco H. 2009. "Globalization and the gender wage gap." World Bank Economic Review 23:141-161.

Sen, Amartya. 1992. "Missing women: Social inequality outweighs women's survival advantage in Asia and North Africa.” British Medical Journal 304:587-588. 
Sen, Mitali, Sonya Rastogi, and Reeve Vanneman. 2006. "Disempowered by whom? Gender vs. generation in family decision making." Unpublished manuscript, Department of Sociology, University of Maryland, College Park, MD.

Topalova, Petia. 2007. "Trade liberalization, poverty and inequality: Evidence from Indian districts." In Globalization and Poverty, edited by Ann Harrison. Chicago: University of Chicago Press, 291-336.

2010. "Factor immobility and regional impacts of trade liberalization: Evidence on poverty from India." American Economic Journal: Applied Economics 2:1-41.

Zweimüller, Martina, Rudolf Winter-Ebmer, and Doris Weichselbaumer. 2008. "Market orientation and gender wage gaps: An international study.” Kyklos 61:615-635. 
Appendix 
Table A1

New State-level Amendments to the 1947 Industrial Disputes Act

\begin{tabular}{|c|c|c|c|c|}
\hline State & Year & Section & Description & Class \\
\hline Gujarat & 2004 & $2 \&$ ch. V-D & $\begin{array}{l}\text { Brings special economic zones (SEZ) under the indus- } \\
\text { trial disputes act. SEZs usually have the status of public } \\
\text { utilities, thus are exempt from some provisions of the } \\
\text { act. The amendment gives a legal framework to SEZs in } \\
\text { Gujarat, and allows termination of workers upon notice } \\
\text { or compensation. While it creates some protection to } \\
\text { workers in SEZs, it also creates a transparent frame- } \\
\text { work for operation of affected businesses. I evaluate } \\
\text { this amendment as pro-employer. }\end{array}$ & -1 \\
\hline Tamil Nadu & 1998 & 7 & $\begin{array}{l}\text { Extension of the qualifications of presiding officer to } \\
\text { serve on a Labour Court to a Government official with } \\
\text { a Law degree. }\end{array}$ & 0 \\
\hline Tamil Nadu & 1998 & $7 \mathrm{~A}$ & $\begin{array}{l}\text { Extension of the qualifications of presiding officer to } \\
\text { serve on an Industrial Tribunal to a Government official } \\
\text { with a Law degree. }\end{array}$ & 0 \\
\hline Delhi & 2003 & 10 & $\begin{array}{l}\text { In the case of an industrial dispute involving an individ- } \\
\text { ual worker he may within a six months period have the } \\
\text { right to apply directly to the Labour Court for adjudica- } \\
\text { tion. No such right is specified in the central act. }\end{array}$ & 1 \\
\hline Madhya Pradesh & 1999 & 7 & $\begin{array}{l}\text { Specification of the qualifications of presiding officer to } \\
\text { serve on a Labour Court to a Government official with } \\
\text { a Law degree. }\end{array}$ & 0 \\
\hline Madhya Pradesh & 2003 & 7 & $\begin{array}{l}\text { Repeals its earlier amendment that increased the power } \\
\text { of the labour court to try offences covered both under } \\
\text { the Industrial Disputes Act as well as offences covered } \\
\text { under a range of other Acts pertaining to labour (which } \\
\text { are specified in the Second Schedule of the Industrial } \\
\text { Disputes Act). }\end{array}$ & 1 \\
\hline Madhya Pradesh & 2003 & 11B - 11D & $\begin{array}{l}\text { Repeals its earlier amendment under which the Labour } \\
\text { Court had all the powers under the Code of Criminal } \\
\text { Procedure of a Judicial Magistrate of the First Clas in } \\
\text { the case of a criminal case. }\end{array}$ & 1 \\
\hline Madhya Pradesh & 2003 & 34 & $\begin{array}{l}\text { Repeals its earlier amendment under which Labour } \\
\text { court is given the power to deal with every offences } \\
\text { punishable under the Labour Disputes Act as well as } \\
\text { under a range of other central acts dealing with labour } \\
\text { issues. }\end{array}$ & 1 \\
\hline West Bengal & 1998 & $7 \mathrm{~A}$ & $\begin{array}{l}\text { Extension of the qualifications of presiding officer to } \\
\text { serve on an Industrial Tribunal to a Government official } \\
\text { with a Law degree. }\end{array}$ & 0 \\
\hline
\end{tabular}

NOTE.-Amendments were collected from Malik (2004) and are coded so that a 1 denotes a change that is pro-labor or antiemployer and a -1 denotes a change that is anti-worker or pro-employer. If there are multiple amendments in a given year, they are evaluated as one. Whenever applicable, new amendments are coded according to the Data Appendix for Besley and Burgess (2004) available at http://econ.lse.ac.uk/staff/rburgess/wp/apptable3.pdf. 
Table A2

Work, Employment and the Regulation of Labor: Robustness Checks

\begin{tabular}{|c|c|c|c|c|c|c|c|c|c|}
\hline \multirow[t]{3}{*}{ Outcome: } & \multicolumn{3}{|c|}{ Any Job (=1) } & \multicolumn{6}{|c|}{ Works for Pay $\lesseqgtr 240$ Days (Base Outcome $=0$ ) } \\
\hline & \multirow[t]{2}{*}{ (1) } & \multirow[t]{2}{*}{ (2) } & \multirow[t]{2}{*}{ (3) } & \multicolumn{2}{|c|}{ (4) } & \multicolumn{2}{|c|}{$(5)$} & \multicolumn{2}{|c|}{ (6) } \\
\hline & & & & $<$ & $\geqq$ & $<$ & $\geqq$ & $<$ & $\geqq$ \\
\hline Base results (Table 4) & \multicolumn{9}{|c|}{ Coefficients on Labor Regulation Variable } \\
\hline Women $(N=18637)$ & $\begin{array}{r}-2.34^{*} \\
(0.41)\end{array}$ & $\begin{array}{c}-2.27^{*} \\
(0.47)\end{array}$ & $\begin{array}{c}-1.96^{*} \\
(0.51)\end{array}$ & $\begin{array}{c}-0.90^{*} \\
(0.17)\end{array}$ & $\begin{array}{r}-1.00^{*} \\
(0.21)\end{array}$ & $\begin{array}{r}-1.00^{*} \\
(0.22)\end{array}$ & $\begin{array}{c}-0.91^{*} \\
(0.21)\end{array}$ & $\begin{array}{r}-0.48^{*} \\
(0.16)\end{array}$ & $\begin{array}{r}-1.01 * \\
(0.23)\end{array}$ \\
\hline Men $(N=18886)$ & $\begin{array}{c}-0.10 \\
(0.22)\end{array}$ & $\begin{array}{c}0.01 \\
(0.21)\end{array}$ & $\begin{array}{c}0.29 \\
(0.25)\end{array}$ & $\begin{array}{c}0.25 \\
(0.30)\end{array}$ & $\begin{array}{r}-1.68^{*} \\
(0.45)\end{array}$ & $\begin{array}{c}0.22 \\
(0.32)\end{array}$ & $\begin{array}{r}-1.98^{*} \\
(0.43)\end{array}$ & $\begin{array}{c}0.79^{+} \\
(0.31)\end{array}$ & $\begin{array}{r}-2.41 * \\
(0.51)\end{array}$ \\
\hline \multicolumn{10}{|l|}{ A: West Bengal dropped } \\
\hline Women $(N=18097)$ & $\begin{array}{c}-2.86^{*} \\
(0.56)\end{array}$ & $\begin{array}{r}-3.56^{*} \\
(0.61)\end{array}$ & $\begin{array}{c}-4.37 * \\
(1.25)\end{array}$ & $\begin{array}{c}-1.11^{*} \\
(0.19)\end{array}$ & $\begin{array}{c}-1.51^{*} \\
(0.18)\end{array}$ & $\begin{array}{r}-1.42^{*} \\
(0.22)\end{array}$ & $\begin{array}{c}-1.47^{*} \\
(0.20)\end{array}$ & $\begin{array}{c}0.17 \\
(0.55)\end{array}$ & $\begin{array}{r}-1.53^{*} \\
(0.39)\end{array}$ \\
\hline Men $\quad(N=18305)$ & $\begin{array}{c}0.02 \\
(0.39)\end{array}$ & $\begin{array}{c}0.20 \\
(0.37)\end{array}$ & $\begin{array}{c}-0.43 \\
(0.78)\end{array}$ & $\begin{array}{c}0.60 \\
(0.56)\end{array}$ & $\begin{array}{r}-5.32^{*} \\
(0.73)\end{array}$ & $\begin{array}{r}-0.54 \\
(0.46)\end{array}$ & $\begin{array}{c}-4.07^{*} \\
(0.74)\end{array}$ & $\begin{array}{c}-0.00 \\
(0.97)\end{array}$ & $\begin{array}{r}-6.71^{*} \\
(1.63)\end{array}$ \\
\hline \multicolumn{10}{|l|}{ B: 6 metro areas dropped } \\
\hline Women $(N=15156)$ & $\begin{array}{r}-2.25^{*} \\
(0.62)\end{array}$ & $\begin{array}{r}-2.20^{*} \\
(0.67)\end{array}$ & $\begin{array}{r}-1.14 \\
(0.65)\end{array}$ & $\begin{array}{r}-1.22^{*} \\
(0.22)\end{array}$ & $\begin{array}{r}-1.20^{*} \\
(0.30)\end{array}$ & $\begin{array}{r}-1.30^{*} \\
(0.25)\end{array}$ & $\begin{array}{c}-1.18^{*} \\
(0.34)\end{array}$ & $\begin{array}{r}-0.47^{*} \\
(0.18)\end{array}$ & $\begin{array}{c}-0.87^{*} \\
(0.28)\end{array}$ \\
\hline Men $(N=15273)$ & $\begin{array}{c}-0.10 \\
(0.28)\end{array}$ & $\begin{array}{c}0.09 \\
(0.27)\end{array}$ & $\begin{array}{c}0.45 \\
(0.27)\end{array}$ & $\begin{array}{r}-0.28 \\
(0.43)\end{array}$ & $\begin{array}{r}-2.78^{*} \\
(0.65)\end{array}$ & $\begin{array}{r}-0.56 \\
(0.41)\end{array}$ & $\begin{array}{c}-2.47^{*} \\
(0.64)\end{array}$ & $\begin{array}{c}0.28 \\
(0.39)\end{array}$ & $\begin{array}{r}-2.50^{*} \\
(0.68)\end{array}$ \\
\hline \multicolumn{10}{|l|}{ C: Only amendments } \\
\hline Women $(N=18637)$ & $\begin{array}{c}-2.17^{*} \\
(0.39)\end{array}$ & $\begin{array}{c}-2.06^{*} \\
(0.46)\end{array}$ & $\begin{array}{r}-1.12 \\
(0.58)\end{array}$ & $\begin{array}{c}-1.14^{*} \\
(0.16)\end{array}$ & $\begin{array}{c}-0.40^{+} \\
(0.18)\end{array}$ & $\begin{array}{r}-1.12^{*} \\
(0.19)\end{array}$ & $\begin{array}{c}-0.42^{+} \\
(0.18)\end{array}$ & $\begin{array}{c}-0.46^{*} \\
(0.18)\end{array}$ & $\begin{array}{r}-0.61^{*} \\
(0.21)\end{array}$ \\
\hline Men $(N=18886)$ & $\begin{array}{r}-0.20 \\
(0.20)\end{array}$ & $\begin{array}{r}-0.02 \\
(0.21)\end{array}$ & $\begin{array}{c}0.57^{+} \\
(0.27)\end{array}$ & $\begin{array}{c}-0.72^{+} \\
(0.30)\end{array}$ & $\begin{array}{r}-0.28 \\
(0.42)\end{array}$ & $\begin{array}{r}-0.24 \\
(0.31)\end{array}$ & $\begin{array}{c}-1.52^{*} \\
(0.44)\end{array}$ & $\begin{array}{c}0.99 * \\
(0.37)\end{array}$ & $\begin{array}{r}-2.10^{*} \\
(0.59)\end{array}$ \\
\hline \multicolumn{10}{|l|}{ D: Reweighted } \\
\hline Women $(N=18637)$ & $\begin{array}{r}-2.60^{*} \\
(0.41)\end{array}$ & $\begin{array}{r}-2.30^{*} \\
(0.44)\end{array}$ & $\begin{array}{r}-1.45^{*} \\
(0.45)\end{array}$ & $\begin{array}{r}-0.59^{*} \\
(0.12)\end{array}$ & $\begin{array}{r}-1.36^{*} \\
(0.27)\end{array}$ & $\begin{array}{r}-0.62^{*} \\
(0.13)\end{array}$ & $\begin{array}{c}-1.30^{*} \\
(0.28)\end{array}$ & $\begin{array}{c}-0.21^{+} \\
(0.09)\end{array}$ & $\begin{array}{c}-1.18^{*} \\
(0.28)\end{array}$ \\
\hline Men $(N=18886)$ & $\begin{array}{c}-0.47 \\
(0.26)\end{array}$ & $\begin{array}{c}-0.39 \\
(0.27)\end{array}$ & $\begin{array}{c}0.15 \\
(0.32)\end{array}$ & $\begin{array}{c}0.48 \\
(0.29)\end{array}$ & $\begin{array}{r}-1.92^{*} \\
(0.48)\end{array}$ & $\begin{array}{c}0.16 \\
(0.27)\end{array}$ & $\begin{array}{r}-2.08^{*} \\
(0.45)\end{array}$ & $\begin{array}{c}0.63^{+} \\
(0.26)\end{array}$ & $\begin{array}{r}-2.24^{*} \\
(0.54)\end{array}$ \\
\hline \multicolumn{10}{|c|}{ E: Pre-1977 characteristics } \\
\hline Women $(N=18637)$ & $\begin{array}{c}-2.21^{*} \\
(0.64)\end{array}$ & $\begin{array}{c}-2.43^{*} \\
(0.66)\end{array}$ & $\begin{array}{c}-3.35^{*} \\
(0.75)\end{array}$ & $\begin{array}{c}-0.25 \\
(0.20)\end{array}$ & $\begin{array}{c}-1.25^{*} \\
(0.25)\end{array}$ & $\begin{array}{c}-0.38 \\
(0.22)\end{array}$ & $\begin{array}{r}-1.09^{*} \\
(0.25)\end{array}$ & $\begin{array}{c}-1.03^{*} \\
(0.32)\end{array}$ & $\begin{array}{r}-1.22^{*} \\
(0.35)\end{array}$ \\
\hline Men $(N=18886)$ & $\begin{array}{c}0.52 \\
(0.34)\end{array}$ & $\begin{array}{c}0.29 \\
(0.33)\end{array}$ & $\begin{array}{r}-0.67 \\
(0.35)\end{array}$ & $\begin{array}{c}2.29 * \\
(0.40)\end{array}$ & $\begin{array}{c}-2.47^{*} \\
(0.70)\end{array}$ & $\begin{array}{c}1.93^{*} \\
(0.42)\end{array}$ & $\begin{array}{c}-1.83^{*} \\
(0.71)\end{array}$ & $\begin{array}{c}1.14^{+} \\
(0.45)\end{array}$ & $\begin{array}{r}-0.81 \\
(0.83)\end{array}$ \\
\hline \multicolumn{10}{|l|}{ F: Rural sample } \\
\hline Women $(N=34898)$ & $\begin{array}{r}-1.99^{*} \\
(0.44)\end{array}$ & $\begin{array}{c}-2.00 * \\
(0.45)\end{array}$ & $\begin{array}{c}-0.82 \\
(0.49)\end{array}$ & $\begin{array}{r}-4.47^{*} \\
(0.44)\end{array}$ & $\begin{array}{r}-1.41^{*} \\
(0.33)\end{array}$ & $\begin{array}{r}-5.23^{*} \\
(0.47)\end{array}$ & $\begin{array}{r}-1.32^{*} \\
(0.32)\end{array}$ & $\begin{array}{r}-4.44^{*} \\
(0.40)\end{array}$ & $\begin{array}{r}-1.15^{*} \\
(0.18)\end{array}$ \\
\hline Men $(N=34955)$ & $\begin{array}{c}0.38 \\
(0.21)\end{array}$ & $\begin{array}{c}0.47^{+} \\
(0.19)\end{array}$ & $\begin{array}{c}0.72^{*} \\
(0.20)\end{array}$ & $\begin{array}{c}0.14 \\
(0.46)\end{array}$ & $\begin{array}{r}-1.46^{*} \\
(0.46)\end{array}$ & $\begin{array}{r}-0.28 \\
(0.46)\end{array}$ & $\begin{array}{r}-1.52^{*} \\
(0.45)\end{array}$ & $\begin{array}{c}-0.33 \\
(0.51)\end{array}$ & $\begin{array}{r}-2.21^{*} \\
(0.42)\end{array}$ \\
\hline
\end{tabular}

NotE.-Table reports coefficients on labor regulation variables from specifications equivalent to those in Table 4. Reported estimates are marginal effects from (multinomial) logit models evaluated at means of explanatory variables and expressed in percents. A: West Bengal is the state with the largest number of amendments (4 in the pro-worker direction). B: Respondents living in the 6 largest metropolitan areas (Mumbai, Delhi, Kolkata, Chennai, Bangalore, and Hyderabad) are dropped. C: The labor regulation measure is replaced by one based only on Besley and Burgess' (2004) methodology and includes the new amendments (see column 2 of Table 1). D: Sampling weights are modified so that their sum is equal across states. E: Pre-1977 characteristics include 1960-1976 state averages of $(\log )$ Net State Domestic Product (NSDP) per capita, population-share of union members, and shares of agriculture; forestry and logging; fishery; mining and quarrying; registered manufacturing' unregistered manufacturing; construction; and water and gas on NSDP. F: The sample is changed to the rural population. Standard errors clustered on households are in parentheses: ${ }^{+} p<0.05, * p<0.01$. 
Table A3

Labor Regulation and the Gender Wage Gap: Robustness Checks

\begin{tabular}{|c|c|c|c|c|c|c|c|}
\hline Outcome: Log Hourly Wage & (1) & (2) & (3) & (4) & $(5)$ & (6) & (7) \\
\hline \multicolumn{8}{|l|}{ Base results (Table 6) $\quad(N=112567)$} \\
\hline Labor regulation & $\begin{array}{c}.032^{+} \\
(.013)\end{array}$ & $\begin{array}{c}.012 \\
(.011)\end{array}$ & $\begin{array}{c}.012 \\
(.009)\end{array}$ & $\begin{array}{c}.012 \\
(.009)\end{array}$ & $\begin{array}{c}.002 \\
(.007)\end{array}$ & $\begin{array}{c}.002 \\
(.007)\end{array}$ & $\begin{array}{c}.002 \\
(.007)\end{array}$ \\
\hline Labor regulation $\times$ woman & $\begin{array}{c}.042^{+} \\
(.021)\end{array}$ & $\begin{array}{c}.039^{+} \\
(.020)\end{array}$ & $\begin{array}{c}.024 \\
(.017)\end{array}$ & $\begin{array}{c}.022 \\
(.017)\end{array}$ & $\begin{array}{c}.020 \\
(.016)\end{array}$ & $\begin{array}{c}.011 \\
(.014)\end{array}$ & $\begin{array}{c}.006 \\
(.014)\end{array}$ \\
\hline \multicolumn{8}{|l|}{ A: West Bengal dropped $(N=10871)$} \\
\hline Labor regulation & $\begin{array}{c}.023 \\
(.019)\end{array}$ & $\begin{array}{c}.020 \\
(.015)\end{array}$ & $\begin{array}{c}.021 \\
(.013)\end{array}$ & $\begin{array}{c}.021 \\
(.013)\end{array}$ & $\begin{array}{c}.009 \\
(.012)\end{array}$ & $\begin{array}{c}.005 \\
(.011)\end{array}$ & $\begin{array}{c}.004 \\
(.010)\end{array}$ \\
\hline Labor regulation $\times$ woman & $\begin{array}{c}.100 * \\
(.027)\end{array}$ & $\begin{array}{c}.083^{*} \\
(.025)\end{array}$ & $\begin{array}{c}.051^{+} \\
(.021)\end{array}$ & $\begin{array}{c}.046^{+} \\
(.021)\end{array}$ & $\begin{array}{c}.033 \\
(.020)\end{array}$ & $\begin{array}{c}.014 \\
(.018)\end{array}$ & $\begin{array}{c}.012 \\
(.018)\end{array}$ \\
\hline \multicolumn{8}{|l|}{ B: 6 metro areas dropped $\quad(N=9534)$} \\
\hline Labor regulation & $\begin{array}{c}.038^{+} \\
(.016)\end{array}$ & $\begin{array}{c}.022 \\
(.014)\end{array}$ & $\begin{array}{c}.014 \\
(.012)\end{array}$ & $\begin{array}{c}.014 \\
(.012)\end{array}$ & $\begin{array}{r}-.001 \\
(.010)\end{array}$ & $\begin{array}{r}-.008 \\
(.010)\end{array}$ & $\begin{array}{r}-.010 \\
(.009)\end{array}$ \\
\hline Labor regulation $\times$ woman & $\begin{array}{c}.046 \\
(.029)\end{array}$ & $\begin{array}{c}.036 \\
(.026)\end{array}$ & $\begin{array}{c}.024 \\
(.022)\end{array}$ & $\begin{array}{c}.019 \\
(.022)\end{array}$ & $\begin{array}{c}.015 \\
(.021)\end{array}$ & $\begin{array}{c}.009 \\
(.018)\end{array}$ & $\begin{array}{c}.009 \\
(.017)\end{array}$ \\
\hline \multicolumn{8}{|l|}{ C: Only amendments $\quad(N=11882)$} \\
\hline Labor regulation & $\begin{array}{c}.052^{*} \\
(.012)\end{array}$ & $\begin{array}{c}.028^{+} \\
(.011)\end{array}$ & $\begin{array}{c}.021^{+} \\
(.009)\end{array}$ & $\begin{array}{c}.021^{+} \\
(.009)\end{array}$ & $\begin{array}{c}.001 \\
(.007)\end{array}$ & $\begin{array}{c}.001 \\
(.007)\end{array}$ & $\begin{array}{c}.002 \\
(.006)\end{array}$ \\
\hline Labor regulation $\times$ woman & $\begin{array}{c}.051^{*} \\
(.018)\end{array}$ & $\begin{array}{c}.049 * \\
(.017)\end{array}$ & $\begin{array}{c}.042^{*} \\
(.014)\end{array}$ & $\begin{array}{c}.038^{*} \\
(.014)\end{array}$ & $\begin{array}{c}.026^{+} \\
(.013)\end{array}$ & $\begin{array}{c}.020 \\
(.012)\end{array}$ & $\begin{array}{c}.019 \\
(.012)\end{array}$ \\
\hline \multicolumn{8}{|l|}{ D: Reweighted $\quad(N=11882)$} \\
\hline Labor regulation & $\begin{array}{c}.037^{*} \\
(.013)\end{array}$ & $\begin{array}{c}.013 \\
(.011)\end{array}$ & $\begin{array}{c}.009 \\
(.008)\end{array}$ & $\begin{array}{c}.010 \\
(.009)\end{array}$ & $\begin{array}{c}.002 \\
(.007)\end{array}$ & $\begin{array}{c}.002 \\
(.007)\end{array}$ & $\begin{array}{c}.002 \\
(.007)\end{array}$ \\
\hline Labor regulation $\times$ woman & $\begin{array}{c}.061^{*} \\
(.022)\end{array}$ & $\begin{array}{c}.055^{*} \\
(.020)\end{array}$ & $\begin{array}{c}.033^{+} \\
(.016)\end{array}$ & $\begin{array}{c}.026 \\
(.016)\end{array}$ & $\begin{array}{c}.026 \\
(.016)\end{array}$ & $\begin{array}{l}.015 \\
(.014)\end{array}$ & $\begin{array}{c}.012 \\
(.014)\end{array}$ \\
\hline \multicolumn{8}{|l|}{ E: Pre-1977 characteristics $\quad(N=11541)$} \\
\hline Labor regulation & $\begin{array}{c}.001 \\
(.020)\end{array}$ & $\begin{array}{c}-.006 \\
(.018)\end{array}$ & $\begin{array}{r}-.012 \\
(.014)\end{array}$ & $\begin{array}{r}-.013 \\
(.014)\end{array}$ & $\begin{array}{r}-.015 \\
(.012)\end{array}$ & $\begin{array}{r}-.011 \\
(.012)\end{array}$ & $\begin{array}{r}-.011 \\
(.011)\end{array}$ \\
\hline Labor regulation $\times$ woman & $\begin{array}{c}.041 \\
(.022)\end{array}$ & $\begin{array}{c}.039 \\
(.021)\end{array}$ & $\begin{array}{c}.023 \\
(.017)\end{array}$ & $\begin{array}{c}.021 \\
(.017)\end{array}$ & $\begin{array}{c}.022 \\
(.017)\end{array}$ & $\begin{array}{c}.012 \\
(.015)\end{array}$ & $\begin{array}{c}.007 \\
(.014)\end{array}$ \\
\hline \multicolumn{8}{|l|}{ F: Rural sample $\quad(N=25254)$} \\
\hline Labor regulation & $\begin{array}{c}.000 \\
(.007)\end{array}$ & $\begin{array}{c}-.005 \\
(.007)\end{array}$ & $\begin{array}{r}-.002 \\
(.006)\end{array}$ & $\begin{array}{c}-.001 \\
(.006)\end{array}$ & $\begin{array}{r}-.003 \\
(.006)\end{array}$ & $\begin{array}{r}-.014^{*} \\
(.005)\end{array}$ & $\begin{array}{r}-.015^{*} \\
(.005)\end{array}$ \\
\hline Labor regulation $\times$ woman & $\begin{array}{c}.037^{*} \\
(.009)\end{array}$ & $\begin{array}{c}.042^{*} \\
(.009)\end{array}$ & $\begin{array}{c}.034^{*} \\
(.008)\end{array}$ & $\begin{array}{c}.035^{*} \\
(.008)\end{array}$ & $\begin{array}{c}.035^{*} \\
(.008)\end{array}$ & $\begin{array}{c}.028^{*} \\
(.007)\end{array}$ & $\begin{array}{l}.032^{*} \\
(.007)\end{array}$ \\
\hline
\end{tabular}

NotE.-Table reports selected coefficients from specifications equivalent to those in Table 6. Reported estimates are coefficients from OLS models. Robustness checks (A through F) are explained in the footnote below Table A2 $N$ refers to the number of observations in specification (7). Standard errors clustered on households are in parentheses: ${ }^{+} p<0.05,{ }^{*} p<0.01$. 
Table A4

Women's Say: Robustness Checks

\begin{tabular}{|c|c|c|c|c|c|c|c|c|}
\hline \multirow{2}{*}{$\begin{array}{l}\text { Outcome: Women } \\
\text { Most-Say Index }(=0-5)\end{array}$} & \multicolumn{4}{|c|}{ Rural } & \multicolumn{4}{|c|}{ Urban } \\
\hline & (1) & (2) & (3) & (4) & $(5)$ & (6) & (7) & (8) \\
\hline & \multicolumn{8}{|c|}{ Coefficients on Labor Regulation Variable } \\
\hline Base results (Table 7) & $\begin{array}{c}-0.063^{+} \\
(0.029)\end{array}$ & $\begin{array}{c}-0.069^{+} \\
(0.030)\end{array}$ & $\begin{array}{c}-0.059^{+} \\
(0.025)\end{array}$ & $\begin{array}{r}-0.098^{*} \\
(0.022)\end{array}$ & $\begin{array}{r}-0.080^{*} \\
(0.019)\end{array}$ & $\begin{array}{r}-0.048^{*} \\
(0.018)\end{array}$ & $\begin{array}{c}-0.049^{*} \\
(0.017)\end{array}$ & $\begin{array}{r}-0.056^{*} \\
(0.020)\end{array}$ \\
\hline A: West Bengal dropped & $\begin{array}{r}-0.294^{*} \\
(0.049)\end{array}$ & $\begin{array}{r}-0.279^{*} \\
(0.051)\end{array}$ & $\begin{array}{c}-0.271^{*} \\
(0.045)\end{array}$ & $\begin{array}{r}-0.421^{*} \\
(0.076)\end{array}$ & $\begin{array}{r}-0.255^{*} \\
(0.034)\end{array}$ & $\begin{array}{r}-0.213^{*} \\
(0.033)\end{array}$ & $\begin{array}{c}-0.214^{*} \\
(0.033)\end{array}$ & $\begin{array}{r}-0.363^{*} \\
(0.063)\end{array}$ \\
\hline \multirow[t]{2}{*}{$\begin{array}{l}\text { B: } 6 \text { metro areas } \\
\text { dropped }\end{array}$} & -0.055 & $-0.058^{+}$ & -0.051 & $-0.086^{*}$ & $-0.167^{*}$ & $-0.133^{*}$ & $-0.126^{*}$ & $-0.093^{*}$ \\
\hline & $(0.029)$ & $(0.028)$ & $(0.028)$ & $(0.023)$ & $(0.031)$ & $(0.029)$ & $(0.029)$ & $(0.026)$ \\
\hline C: Only amendments & $\begin{array}{c}0.007 \\
(0.028)\end{array}$ & $\begin{array}{c}0.005 \\
(0.028)\end{array}$ & $\begin{array}{c}0.019 \\
(0.022)\end{array}$ & $\begin{array}{r}-0.080^{*} \\
(0.027)\end{array}$ & $\begin{array}{r}-0.037^{+} \\
(0.017)\end{array}$ & $\begin{array}{c}-0.013 \\
(0.016)\end{array}$ & $\begin{array}{l}-0.001 \\
(0.016)\end{array}$ & $\begin{array}{r}-0.051^{+} \\
(0.022)\end{array}$ \\
\hline D: Reweighted & $\begin{array}{c}-0.066^{+} \\
(0.034)\end{array}$ & $\begin{array}{c}-0.074^{+} \\
(0.034)\end{array}$ & $\begin{array}{c}-0.065^{+} \\
(0.028)\end{array}$ & $\begin{array}{r}-0.076^{*} \\
(0.023)\end{array}$ & $\begin{array}{r}-0.067^{*} \\
(0.019)\end{array}$ & $\begin{array}{r}-0.033 \\
(0.018)\end{array}$ & $\begin{array}{c}-0.025 \\
(0.018)\end{array}$ & $\begin{array}{r}-0.045^{+} \\
(0.021)\end{array}$ \\
\hline
\end{tabular}

NotE.-Table reports coefficients on the labor regulation variable from specifications equivalent to those in Table 7. The "women most-say index" is defined in the note below that table. Reported estimates are coefficients from tobit models $($ lower limit=0, upper limit=5). Robustness checks (A through D) are explained in the footnote below Table A2. Sample: all households. Standard errors are in parentheses: $+p<0.05, * p<0.01$.

Table A5

Women in the Population: Robustness Checks

\begin{tabular}{|c|c|c|c|c|c|c|c|c|}
\hline \multirow[b]{2}{*}{ Outcome: Woman $(=1)$} & \multicolumn{4}{|c|}{ Rural } & \multicolumn{4}{|c|}{ Urban } \\
\hline & (1) & (2) & (3) & (4) & $(5)$ & (6) & (7) & (8) \\
\hline & \multicolumn{8}{|c|}{ Coefficients on Labor Regulation Variable } \\
\hline Base results (Table 8) & $\begin{array}{c}0.113 \\
(0.122)\end{array}$ & $\begin{array}{c}0.133 \\
(0.124)\end{array}$ & $\begin{array}{c}0.073 \\
(0.120)\end{array}$ & $\begin{array}{c}-0.071 \\
(0.133)\end{array}$ & $\begin{array}{c}-0.358 * \\
(0.099)\end{array}$ & $\begin{array}{c}-0.329 * \\
(0.102)\end{array}$ & $\begin{array}{r}-0.371^{*} \\
(0.105)\end{array}$ & $\begin{array}{r}-0.413^{*} \\
(0.122)\end{array}$ \\
\hline A: West Bengal dropped & $\begin{array}{c}0.166 \\
(0.224)\end{array}$ & $\begin{array}{c}0.278 \\
(0.230)\end{array}$ & $\begin{array}{c}0.144 \\
(0.217)\end{array}$ & $\begin{array}{c}-1.346^{*} \\
(0.400)\end{array}$ & $\begin{array}{c}-0.410^{+} \\
(0.172)\end{array}$ & $\begin{array}{c}-0.353^{+} \\
(0.175)\end{array}$ & $\begin{array}{c}-0.477^{*} \\
(0.183)\end{array}$ & $\begin{array}{r}-0.227 \\
(0.401)\end{array}$ \\
\hline B: 6 metro areas dropped & $\begin{array}{r}-0.013 \\
(0.119)\end{array}$ & $\begin{array}{c}0.023 \\
(0.123)\end{array}$ & $\begin{array}{r}-0.007 \\
(0.127)\end{array}$ & $\begin{array}{r}-0.203 \\
(0.139)\end{array}$ & $\begin{array}{r}-0.197 \\
(0.144)\end{array}$ & $\begin{array}{r}-0.166 \\
(0.145)\end{array}$ & $\begin{array}{r}-0.227 \\
(0.149)\end{array}$ & $\begin{array}{r}-0.221 \\
(0.158)\end{array}$ \\
\hline C: Only amendments & $\begin{array}{c}0.057 \\
(0.120)\end{array}$ & $\begin{array}{c}0.064 \\
(0.119)\end{array}$ & $\begin{array}{c}0.007 \\
(0.113)\end{array}$ & $\begin{array}{c}0.152 \\
(0.147)\end{array}$ & $\begin{array}{c}-0.300^{*} \\
(0.102)\end{array}$ & $\begin{array}{c}-0.305^{*} \\
(0.106)\end{array}$ & $\begin{array}{c}-0.352^{*} \\
(0.110)\end{array}$ & $\begin{array}{r}-0.437^{*} \\
(0.134)\end{array}$ \\
\hline D: Reweighted & $\begin{array}{c}0.171 \\
(0.130)\end{array}$ & $\begin{array}{c}0.198 \\
(0.129)\end{array}$ & $\begin{array}{c}0.110 \\
(0.122)\end{array}$ & $\begin{array}{r}-0.012 \\
(0.133)\end{array}$ & $\begin{array}{r}-0.276^{*} \\
(0.099)\end{array}$ & $\begin{array}{r}-0.240^{+} \\
(0.103)\end{array}$ & $\begin{array}{r}-0.332^{*} \\
(0.104)\end{array}$ & $\begin{array}{r}-0.412^{*} \\
(0.120)\end{array}$ \\
\hline E: Age from 18 to 65 & $\begin{array}{c}0.016 \\
(0.114)\end{array}$ & $\begin{array}{c}0.012 \\
(0.114)\end{array}$ & $\begin{array}{r}-0.047 \\
(0.118)\end{array}$ & $\begin{array}{c}-0.261^{+} \\
(0.130)\end{array}$ & $\begin{array}{c}-0.270^{*} \\
(0.097)\end{array}$ & $\begin{array}{c}-0.256^{+} \\
(0.102)\end{array}$ & $\begin{array}{r}-0.309 * \\
(0.104)\end{array}$ & $\begin{array}{r}-0.400^{*} \\
(0.116)\end{array}$ \\
\hline F: Age more than 65 & $\begin{array}{c}0.588 \\
(0.784)\end{array}$ & $\begin{array}{c}0.493 \\
(0.753)\end{array}$ & $\begin{array}{c}0.450 \\
(0.712)\end{array}$ & $\begin{array}{c}0.941 \\
(0.782)\end{array}$ & $\begin{array}{c}-1.135^{+} \\
(0.537)\end{array}$ & $\begin{array}{c}-1.240^{+} \\
(0.549)\end{array}$ & $\begin{array}{c}-1.344^{+} \\
(0.569)\end{array}$ & $\begin{array}{c}0.137 \\
(0.792)\end{array}$ \\
\hline G: Age less than 6 & $\begin{array}{c}0.256 \\
(0.404)\end{array}$ & $\begin{array}{c}0.226 \\
(0.417)\end{array}$ & $\begin{array}{c}0.167 \\
(0.429)\end{array}$ & $\begin{array}{c}0.075 \\
(0.499)\end{array}$ & $\begin{array}{c}0.702 \\
(0.466)\end{array}$ & $\begin{array}{c}0.794 \\
(0.470)\end{array}$ & $\begin{array}{c}0.772 \\
(0.485)\end{array}$ & $\begin{array}{r}1.045^{+} \\
(0.525)\end{array}$ \\
\hline
\end{tabular}

NOTE.-Table reports coefficients on labor regulation variables from specifications equivalent to those in Table 8 . Reported estimates are marginal effects from logit models evaluated at means of explanatory variables, separately for men and women, expressed in percents. Robustness checks (A through D) are explained in the footnote below Table A2. Standard errors clustered on households are in parentheses: ${ }^{+} p<0.05,{ }^{*} p<$ 0.01 . 


\section{Table A6}

\section{Variable Definitions}

Name

Labor regulation

Any job

Poor

Consumption per capita

Log district

consumption p. c.
Works for pay

\section{Definition}

Combined measure of labor regulation based on amendments to 1947 Industrial Disputes Act as reported in Malik (1997) and Investment climate index from Goswami et al. (2002). See section 3.1 and Table 1.

Equals to 1 if a respondent has any job (i.e. works for someone else or in a family business or farm) and worked more than 240 hours during last 12 months, it is 0 otherwise.

Equals 1 if a respondent works for pay (i.e. works for someone else) and worked less than 240 days (and more than 240 hours) during past 24 months, it is 2 if days worked exceed 240, and it is equal to 0 in other cases (the respondent works in a family business or farm, or hours worked during past 12 months are less than 240).

Equals 1 if the household's consumption is below the official (Planning Commission as of 2005) poverty line. The poverty line varies by state and urban/rural residence. It is based on the 1970s calculations of income needed to support minimal calorie consumption and has been adjusted by price indexes since then. It is currently under revision.

Based on a series of 47 questions about household consumption designed to estimate total household consumption expenditures.

Log of mean consumption per capita at district level.

IHDS asks whether anybody in the household belongs to a trade union, business or professional group. I define district unionization as share of households with such a member (conditional on household head being aged between 18 and 65)

District government Is share of government employees on district population (aged between 18 and 65).

employment

6 metro areas

Industries' shares on

labor-force

Casts \& religions

Potential experience

5 -year cohorts

Women most-say

index
Equals 1 if a respondent lives in one of the 6 largest metropolitan areas: Mumbai, Delhi, Kolkata, Chennai, Bangalore, and Hyderabad. (Gurgaon district in Haryana and Ghaziabad and Gautam Buddha Nagar districts in Uttar Pradesh are included as part of the Delhi metropolitan area.)

A matrix of 10 variables matching one digit (NIC) industries, each of which captures share of workers in that industry on urban labor-force in a given state.

A matrix of 14 dummy variables indicating cast (Brahmin, Other Backward Classes, Scheduled Castes, ST Scheduled Tribes, and "Other") and religion (Hindu, Muslim, Christian, Sikh, Buddhist, Jain, Tribal, "Other", and None) of a respondent.

Is defined as (age-years of education-5).

A matrix of dummy variables indicating 5-year birth cohorts.

Counts number of cases in which the respondent identified herself as the one who has the most say in response to following 5 questions: What to cook on a daily basis; whether to buy an expensive item such as a TV or fridge; how many children you have; what to do if a child falls sick; and who should your children marry? The respondent is the "eligible woman", i.e.
Variation

state

individual

individual

household

household

district

district

district

individual

state

individual

individual individual household

\footnotetext{
"an ever married woman between the ages of 15 and 49" in a household.
} 


\section{Working Paper Series}

ISSN 1211-3298

Registration No. (Ministry of Culture): E 19443

Individual researchers, as well as the on-line and printed versions of the CERGE-EI Working Papers (including their dissemination) were supported from institutional support RVO 67985998 from Economics Institute of the ASCR, v. v. i.

Specific research support and/or other grants the researchers/publications benefited from are acknowledged at the beginning of the Paper.

(c) Josef Montag, 2013

All rights reserved. No part of this publication may be reproduced, stored in a retrieval system or transmitted in any form or by any means, electronic, mechanical or photocopying, recording, or otherwise without the prior permission of the publisher.

Published by

Charles University in Prague, Center for Economic Research and Graduate Education (CERGE) and

Economics Institute of the ASCR, v. v. i. (EI)

CERGE-El, Politických vězňů 7, 11121 Prague 1, tel.: +420 224005 153, Czech Republic.

Printed by CERGE-EI, Prague

Subscription: CERGE-EI homepage: http://www.cerge-ei.cz

Phone: + 420224005153

Email: office@cerge-ei.cz

Web: http://www.cerge-ei.cz

Editor: Michal Kejak

The paper is available online at http://www.cerge-ei.cz/publications/working_papers/.

ISBN 978-80-7343-292-8 (Univerzita Karlova. Centrum pro ekonomický výzkum a doktorské studium)

ISBN 978-80-7344-284-2 (Národohospodářský ústav AV ČR, v. v. i.) 
CERGE-EI

P.O.BOX 882

Politických vězňů 7

11121 Praha 1

Czech Republic http://www.cerge-ei.cz 